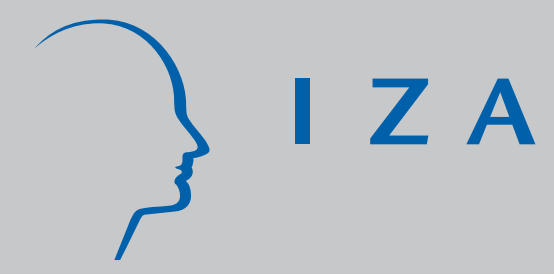

IZA DP No. 3924

Labour Market Dynamics in Australia:

What Drives Unemployment?

Marika Karanassou

Hector Sala

J anuary 2009 


\title{
Labour Market Dynamics in Australia: What Drives Unemployment?
}

\author{
Marika Karanassou \\ Queen Mary, University of London \\ and IZA \\ Hector Sala \\ Universitat Autònoma de Barcelona \\ and IZA
}
Discussion Paper No. 3924
January 2009

IZA
P.O. Box 7240
53072 Bonn
Germany

Phone: +49-228-3894-0

Fax: +49-228-3894-180

E-mail: iza@iza.org

\begin{abstract}
Any opinions expressed here are those of the author(s) and not those of IZA. Research published in this series may include views on policy, but the institute itself takes no institutional policy positions.

The Institute for the Study of Labor (IZA) in Bonn is a local and virtual international research center and a place of communication between science, politics and business. IZA is an independent nonprofit organization supported by Deutsche Post World Net. The center is associated with the University of Bonn and offers a stimulating research environment through its international network, workshops and conferences, data service, project support, research visits and doctoral program. IZA engages in (i) original and internationally competitive research in all fields of labor economics, (ii) development of policy concepts, and (iii) dissemination of research results and concepts to the interested public.
\end{abstract}

IZA Discussion Papers often represent preliminary work and are circulated to encourage discussion. Citation of such a paper should account for its provisional character. A revised version may be available directly from the author. 


\section{ABSTRACT}

\section{Labour Market Dynamics in Australia: What Drives Unemployment?*}

The debate in Australia on the (constant-output) elasticity of labour demand with respect to wages has wrongly sidelined the role of capital stock as a determinant of employment (Webster, 2003). As far back as 1991, Pissarides had argued that the influence of capital stock on the performance of the labour market is crucial but not well understood, a research area which is particularly relevant for Australia. This paper attempts to fill this void by estimating a multi-equation labour market model comprising labour demand, wage setting and labour supply equations. The model is used to examine the causes of the unemployment upturn in 1973-1983 and the subsequent decline in 1993-2006. Our results show that (i) the main determinants of the unemployment rise in the 1970s and early 1980s were wage-push factors, the two oil price shocks and the increase in interest rates, and (ii) the acceleration in capital accumulation was the crucial driving force of unemployment in the 1990s and 2000s. Furthermore, although the recent boom in the terms of trade is equally important, its downward effect on unemployment was partially reversed by the resulting decrease in net foreign demand.

JEL Classification: E22, E24, J21

Keywords: labour market dynamics, capital accumulation, chain reaction theory

Corresponding author:

Hector Sala

Department d'Economia Aplicada

Universitat Autònoma de Barcelona

08193 Bellaterra

Spain

E-mail: hector.sala@uab.es

\footnotetext{
* The bulk of this work was completed while Hector Sala was visiting the School of Economics at the University of New South Wales (Sydney, Australia). Their warm hospitality, as well as the insightful comments and suggestions received from Glenn Otto, are gratefully acknowledged. Hector Sala is grateful to the Spanish Ministry of Education and Science for financial support through grant SEJ2006$14849 / E C O N$ and the mobility program 'Jose Castillejo'.
} 


\section{Introduction}

The relationship between aggregate employment and real wages has attracted a lot of attention in Australia. It is common in most studies to estimate labour demand equations with output, rather than capital stock, as an explanatory variable. However, Webster (2003) argues that "...there is no theoretical reason why the estimating function should include output as an explanatory variable. ...Little discussion is given in the literature of this issue and its practice is questionable." [p. 141]

More than fifteen years ago, Pissarides (1991) estimated a three-equation model for the Australian labour market, where capital stock featured as a determinant of employment and the wage rate. In his global appraisal of Australia's unemployment experience, Pissarides (1991) pointed out that "the links between capital, investment and employment are crucial but they are not very well understood. I make an attempt to discuss them and to bring out the role of investment in the ups and downs of employment in the 1980s. But much more work is needed in this area. In Australia even more than in other countries, this area of research seems to hold much promise of important results." [p. 36]

In the light of the arguments by Webster (2003) on the estimation of employment equations, and the largely disregarded points raised by Pissarides (1991), the objective of this paper is twofold. First, we provide an updated estimation of labour demand using capital stock, rather than output, as a determinant of the Australian employment. It should be noted that, as in Lewis and MacDonald (2002), our estimation follows the autoregressive distributed lag (ARDL) approach to cointegration analysis (but using capital stock instead of output as a determinant of employment). Second, we assess the driving forces of unemployment over the 1972-2006 period in the context of a labour market model comprising, as in Pissarides (1991), employment, wage setting and labour force equations.

There are two stark differences between the work of Pissarides and ours. First, in the Pissarides model capital stock does not influence employment in the steady state, since its direct effect on employment is exactly offset by its indirect effect via wages (capital stock raises the wage rate which, in turn, decreases employment). This is in the spirit of Layard, Nickell and Jackman (1991) and the non-accelerating inflation rate of unemployment (NAIRU) framework of analysis, where there is no room for growing variables to influence the unemployment rate. Second, investment (i.e., the growth rate of capital stock), through its positive effect on wages, ends up having a negative effect on employment and a positive one on unemployment. According to Pissarides (1991) “...this effect is probably due to new technology embodied in the capital stock, which displaces labour faster when it takes place at a higher rate, so that it leads to a higher equilibrium unemployment rate. It may also be due to the peculiarly narrow-based investment booms in Australia and the wage spillovers that they caused elsewhere in the economy." [p. 43-44]

In contrast to the above work, this paper follows the chain reaction theory (CRT) of unem- 
ployment, presented in Section 3, and shows that capital stock affects positively employment in the long-run, while capital accumulation is inversely related with the ups and downs of the unemployment rate. The contribution of capital stock to the evolution of unemployment is among the several important considerations which distinguish the CRT from the NAIRU framework of analysis. ${ }^{1}$ In fact, the significant influence of capital stock on unemployment has become one of the salient empirical facts unveiled by the CRT in studies for the UK (Henry, Karanassou and Snower, 2000; Karanassou and Snower, 2004), the EU (Karanassou, Sala and Snower, 2003), the Nordic countries (Karanassou, Sala and Salvador, 2008), and Spain (Bande and Karanassou, 2009; Karanassou and Sala 2009). ${ }^{2}$

Here we aim at evaluating how capital stock and other supply- and demand-side factors have shaped the unemployment rate trajectory. The role of capital accumulation in the Australian economy is of special interest, since the unemployment effect of capital stock has been largely sidelined in the relevant literature. Our work implicitly responds to Gregory (2000), who argues that "Perhaps we cannot proceed far with simple analysis as it has been applied here except to show that common views and prescriptions do not accord well with the data. This suggests that more complex analysis capable of taking into account many influences at the same time is needed." [p. 124]

Our empirical three-equation model features a variety of feedback mechanisms and includes a wide set of explanatory variables. The estimated system tracks fairly well the actual evolution of Australian unemployment, and is thus used to assess the relative influence of the explanatory variables in shaping its trajectory during two distinct eras: 1973-1983, when rising unemployment attained an historical maximum; and 1993-2006, when falling unemployment reached almost full-employment levels.

Our results for the 1970s and early 1980s are supportive of the mainstream view that shocks (oil prices and interest rates) and institutions (direct taxes, benefits and income policies) are responsible for the increase in the unemployment rate. However, this is not the whole story, as an external factor (e.g. terms of trade) and a Keynesian policy in the late 1970s were also identified among the driving forces of unemployment. In particular, unemployment would have been even higher from 1976 to 1980 had the government not increased its expenditures. As we show in Section 3, one advantage of the CRT approach is that it enables us to test whether trended variables (such as capital accumulation or working-age population) affect unemployment. We find that, although the overall contribution of the growing variables over the 1973-1983 period was minimal, the slow-down in capital accumu-

\footnotetext{
${ }^{1}$ See Karanassou, Sala and Salvador (2008), and Karanassou, Sala and Snower (2009) for a comprehensive exposition of the differences between the CRT and NAIRU.

${ }^{2}$ Apart from the CRT approach, the impact of capital stock on unemployment is becoming the focal point of analysis in other studies as well. Rowthorn (1999) and Kapadia (2005) examine production functions less restrictive than the standard Cobb-Douglas one, while Malley and Moutos (2001) augment the NAIRU framework with strategic trade policy models. Arestis, Baddeley and Sawyer (2007) investigate the capitalunemployment relation in the context of Robert Rowthorn's 1977 aspirations gap model.
} 
lation in the mid 1970s had prolonged and significant effects on unemployment until the end of the decade.

One of our main findings is the crucial effect of capital accumulation on the decline in unemployment over the 1993-2006 period. We show that it accounts for $80 \%$ of the overall fall in unemployment. Had capital stock growth stayed constant at its 1993 value, unemployment would have ended the period about 5 percentage points higher that it actually did. The external factors remain important, especially in the 2000s, but the continuing deterioration of net foreign demand partially negates the contribution of the terms of trade to the declining unemployment (which otherwise would be as large as the contribution of capital stock growth). In sharp contrast with the 1973-1983 period, institutional factors play no role in the performance of the Australian labour market during the 1993-2006 years.

The rest of the paper is structured as follows. Section 2 outlines some crucial aspects of the literature on the labour demand in Australia. Section 3 presents the CRT approach. Section 4 estimates of a CRT multi-equation labour market model for Australia from 1972 to 2006. Section 5 discusses the economic and political developments during our sample period. In the context of our empirical CRT model, Section 6 evaluates the contributions of the exogenous variables (capital stock among them) to the unemployment rate trajectory. Section 7 concludes.

\section{Some Key Features of the Literature on Australia}

The impact of wage changes on (un)employment is a crucial issue, especially since most labour market policies influence wage setting. In Australia, a tradition of centralised wage bargaining and a long experience of income policies implemented through the Accord (or 'Prices and Incomes Accord') have given rise to a prolific literature on this issue.

Webster (2003), surveying the Australian and overseas literature, documents a constantoutput elasticity of labour demand with respect to wages in the range of -0.15 to -0.80 . The "constant-output" adjective signifies that it is a partial elasticity, since it is estimated by holding the endogenous output constant, a practice criticised by Webster (2003, p. 138) as "careless" because it fails to capture the full effect of real wages on labour demand. Instead, Webster (2003) argues that the total elasticity should be estimated by taking into account the response of output to variations in labour as a crucial production factor. Following the analysis of the archetypal aggregate supply-side model, where the total cost of production is minimised subject to the production function, the implication for the profit-maximising firm is that its labour demand equation includes capital stock as a determinant, rather than output. Thus, when output enters the estimated labour demand equation there is the problem of potential endogeneity, which is a serious concern for the results of most of this literature. ${ }^{3}$

\footnotetext{
${ }^{3}$ Even the very recent study on an employment equation for Australia (Dixon, Freebairn and Lim, 2005)
} 
Webster (2003), like Pissarides (1991), shows that labour demand should depend on wages and real interest rates (as the relevant prices of the production factors) and capital stock (as one of the main production factors). Of course, other variables, such as technological change and demand-side variables, can be considered as determinants of labour demand. Most of the studies for Australia consider a standard Hicks-neutral, rather than Harrod-neutral, characterisation of technical progress by including a linear time trend in the employment equation (for a list see Lewis and MacDonald, 2004, p. 444). Although, as pointed out by Webster (2003), most of the literature has tended to ignore any demand-side influences, Pissarides (1991, pp. 41-42) argues for the possibility of aggregate demand effects (see also Lindbeck and Snower, 1994) and gives evidence for demand-side influences in his estimated employment equation.

In terms of the estimation procedure, Lewis and MacDonald (2002) apply the same econometric technique used in this paper (and generally in the papers which estimate CRT models): ${ }^{4}$ the autoregressive distributed lag (ARDL) approach (also known as bounds testing approach) to cointegration analysis. The ARDL was developed by Pesaran (1997), Pesaran and Shin (1999), and Pesaran, Shin and Smith (2001) as an alternative procedure to the standard cointegration/error-correction analysis. One of the main advantages of the ARDL is that it avoids the pretesting issues of identifying the $\mathrm{I}(1)$ or $\mathrm{I}(0)$ properties of the variables, a problem that accompanies the popular cointegration methodologies (like the Johansen maximum likelihood). The voluminous literature on all the different types of unit root tests developed since the influential paper by Dickey and Fuller in Econometrica 1981, is a clear manifestation of the problems involved in testing whether a time series is integrated of order zero or one. It can be shown that the ARDL provides a robust econometric tool for estimating and testing the short- and long-run relationships between the variables without having to classify them as $\mathrm{I}(1)$ or $\mathrm{I}(0)$. In addition, as Lewis and MacDonald (2002) explain, the ARDL is capable of dealing with the endogeneity issues that might arise when output is used in the labour demand equation. We can further argue for the robustness of the empirical results by checking whether the long-run solution of the estimated equation via the ARDL methodology is in line with the cointegrating vector obtained by the Johansen procedure (see Lewis and MacDonald, 2002; Karanassou and Snower, 2004; and Karanassou, Sala and Salvador, 2008).

Lewis and MacDonald (2002) use quarterly data for Australia over the 1961-1998 period and estimate dynamic versions of the labour demand equation $n_{t}=a_{0}+a_{1} w_{t}+a_{2} y_{t}+a_{3} t+\varepsilon_{t}$ (equation (6) in p. 20), where $n_{t}, w_{t}$, and $y_{t}$ represent the (log of) employment, real wage, and real GDP, respectively, $t$ is a time-trend, $\varepsilon_{t}$ denotes the error term, and the $a$ 's are constants. They find weak exogeneity for the right-hand side variables and estimate the

is in line with the conventional use of output as an exogenous determinant of labour demand.

${ }^{4}$ See, for example, Karanassou and Snower (1998), Karanassou, Sala, and Snower (2003), and Karanassou, Sala, and Salvador (2008). 
following long-run relationship (cointegrating vector): ${ }^{5}$

$$
\left(\begin{array}{llll}
n & w & y & t
\end{array}\right)=\left(\begin{array}{llll}
-1 & -0.46 & 1.05 & -0.003
\end{array}\right)
$$

We replicated the results of Lewis and MacDonald (2002) by using our annual dataset from 1970 to 2006 (see Section 4.1 for data description). In particular, following the ARDL approach, our selected dynamic specification of their labour demand equation features two annual lags (versus their seven quarterly lags) and has the following long-run solution:

$$
\left(\begin{array}{llll}
n & w & y & t
\end{array}\right)=\left(\begin{array}{llll}
-1 & -0.50 & 0.97 & -0.009
\end{array}\right)
$$

We confirmed the robustness of the above long-run relationship by finding that it is not statistically different from the cointegrating vector obtained by the Johansen procedure (see Section 4.1 for the details of the LR test used).

Despite using the same econometric technique as Lewis and MacDonald (2002) for the estimation of the labour demand equation, our empirical model in Section 4 differs from theirs (and from most of the existing literature) in two main respects. First, we take into account both Webster's (2003) concerns about the use of output in the labour demand equation, and Pissarides' (1991) intuition that capital stock may yield valuable insights in explaining labour market outcomes in Australia. Second, we use a dynamic multi-equation system with spillover effects, i.e. our model examines labour demand in conjunction with wage setting and labour supply, and, thus, takes into account all interactions among them. A distinguishing characteristic of our empirical analysis is that it does not focus on the computation of the NRU but, instead, provides an account of how the driving forces of employment, wages and the labour force contribute to the evolution of the unemployment rate. We should point out that, because our model derives from the chain reaction theory (CRT) of unemployment, it has radically different implications for the impact of capital accumulation on employment from the Pissarides' (1991) model.

Beyond the studies concerned with the aggregate labour demand, the literature on the unemployment rate is closely linked with the estimation of the equilibrium rate of unemployment, commonly referred to as the NRU or the non-accelerating inflation rate of unemployment (NAIRU). Several papers follow the work by Lilien (1982) who estimated a microfounded reduced-form unemployment equation for the US. This group includes the study by Groenewold and Hagger (1998) who estimated the NRU for 1979-1993, the subsequent debate on the validity of such estimates (McDonald, 1999, Groenewold and Hagger, 1999), and the

\footnotetext{
${ }^{5}$ Because this is obtained from a marginal productivity condition, Lewis and MacDonald (2002) use these values, together with a labour share of 0.6 , to compute (i) the implied constant-output elasticity, which they place below -0.20 , and (ii) the 'correct' elasticity of demand for labour with respect to real wages, which they find equal to -0.80. This interpretation prompted a hot debate (see, among others, Dowrick and Wells, 2004; and Lewis and MacDonald, 2004), which is beyond the scope of our analysis.
} 
more recent work by Heaton and Oslington (2002). Other papers base their analysis on the estimation of the Beveridge curve (e.g. Groenewold, 2003, and Kennedy et al. 2008). However, the main strand of this literature estimates the NAIRU within a Phillips curve context (see Gruen et al., 1999, for a general appraisal). The NAIRU is estimated by (i) applying the Kalman filter technique (Debelle and Vickery, 1998), (ii) using VAR (Crosby and Olekalns, 1998) and SVAR models (Groenewold and Hagger, 2000), and (iii) by embedding the Phillips curve into a big macroeconomic model such as the Treasury macroeconomic (TRYM) model (Song and Freebairn, 2005). Finally, Lye et al. (2001), and Lye and McDonald (2006) use the range model (which allows for a piece-wise linear short-run Phillips curve), to evaluate the minimum equilibrium rate of unemployment, and contrast their model to NRU specifications.

No matter how the equilibrium rate of unemployment is perceived, it is now widely acknowledged that it is hard to agree on its value at any point in time. ${ }^{6}$ Hagger and Groenewold (2003) claim that it is time to ditch the natural rate, since "it has become a source of great and growing confusion" [p. 324]. Lye and McDonald (2006) conclude that "basing macroeconomic policy on the natural rate model would underpin the possibilities for economic welfare in Australia" [p. 227]. McDonald (2008) remarks that "the usefulness of the TV NAIRU is bedeviled by the lack of explicit economic mechanisms to determine its movements. It lets the data talk, but, uninstructed, the data can tell little". [p. 283]

In next Section we present the workings of the CRT within a stylised framework of analysis and explain how it differs from the conventional wisdom. We show that, under plausible conditions, unemployment does not gravitate towards its natural rate and, therefore, the pivotal role of the NRU in policy making is questionable. ${ }^{7}$

\section{The Chain Reaction Theory}

The chain reaction theory (CRT) is an interactive dynamics approach aiming at explaining the evolution of the unemployment rate within a framework of a dynamic multi-equation model, which allows for spillovers effects and growing variables.

In essence, the CRT postulates that the movements in unemployment are driven by the interplay of shocks and lagged adjustment processes. Generally, the CRT refers to lags of the endogenous variables as the lagged adjustment processes. Shocks refer to changes in the exogenous variables, while lagged adjustment processes refer to, among others, employment adjustments, wage/price staggering, insider membership effects, long-term unemployment effects, and labour force adjustments. Spillovers arise when endogenous variables have ex-

\footnotetext{
${ }^{6}$ See, for example, The Economist, 30 September 2006, p. 108.

${ }^{7}$ Since our focus is on the real side of the economy, we do not consider nominal variables and, thus, we refer to the NRU rather than the NAIRU. Karanassou, Sala and Snower (2008) examine a CRT model consisting of both real and nominal variables. For a discussion of NRU, NAIRU, and CRT models see Karanassou, Sala and Snower (2009).
} 
planatory power in other equations of the system and, thus, generate interactive dynamics. So speaking, the chain reaction adjective highlights the intertemporal responses of the unemployment rate to changes in the exogenous variables (shocks) propagated by a network of interacting lags.

Another main feature of the CRT is that the unemployment trajectory is influenced not only by stationary variables (such as oil prices or interest rates) but by trended variables (such as capital stock and working-age population) as well. Therefore, it has the capacity of accounting for the unemployment effects of both temporary and permanent shocks to the labour market. This contradicts the conventional wisdom as it is expressed by the natural rate of unemployment (NRU) theory. Furthermore, we should point out that the interplay of lags and changes in growing variables gives rise to frictional growth.

In what follows, we give a brief outline of the popular natural rate hypothesis, explain analytically the phenomenon of frictional growth and how it challenges the NRU, and present the CRT via a stylised labour market model.

\subsection{The Natural Rate Hypothesis}

In macro-labour modelling the NRU $\left(u^{n}\right)$ is generally defined as the equilibrium value at which unemployment stabilises in the long-run (see, for example, Ball and Mankiw, 2002).

Based on the observation that, on average, the unemployment rate has been trendless over several decades, the dominant view in the literature argues that growing variables cannot influence its value in the long-run (i.e. the NRU). The simplest illustration of this conventional wisdom is the following dynamic single-equation model (for expositional ease we consider an $\mathrm{AR}(1)$ process with one determinant, and ignore the error term):

$$
u_{t}=\alpha u_{t-1}+\beta x_{t}
$$

where $u_{t}$ denotes the unemployment rate, $x_{t}$ is an exogenous variable, the autoregressive parameter $\alpha$ is less than one in absolute value, and $\beta$ is a constant.

Let us reparameterise the above autoregression as

$$
u_{t}=\frac{\beta}{1-\alpha} x_{t}-\frac{\alpha}{1-\alpha} \Delta u_{t}
$$

where $\Delta$ denotes the difference operator. In the long-run, assuming that $x_{t}$ is not growing, the unemployment rate stabilises (i.e. $u_{t}=u_{t-1} \Leftrightarrow \Delta u_{t}=0$ ) and so the above equation reduces to its steady-state and gives the NRU:

$$
u^{n}=\frac{\beta}{1-\alpha} x^{L R} .
$$

where the superscript ${ }^{L R}$ denotes the long-run value of the variable. In this case, the first 
term of (2) can be interpreted as "trend" unemployment and the second one as "cyclical" unemployment.

\subsection{The Phenomenon of Frictional Growth}

Let us rewrite the above pedagogical $\mathrm{AR}(1)$ equation (2) in terms of some endogenous variable $y_{t}$ :

$$
y_{t}=\underbrace{\frac{\beta}{1-\alpha} x_{t}}_{\text {"trend" or steady-state }}-\underbrace{\frac{\alpha}{1-\alpha} \Delta y_{t}}_{\substack{\text { "cycle" if long-run growth=0 } \\ \text { "frictional growth" otherwise }}} .
$$

Note that, while the first term of the above equation captures the "trend" of $y_{t}$, the second term describes its cyclical variations if the growth of the $x_{t}$ is zero in the long run. If however, the exogenous variable $x_{t}$ has a nonzero long-run growth rate, the second term of (4) gives rise to frictional growth. In other words, frictional growth results from the interplay of lags and growth. It is also worth noting that the long-run elasticity of $y$ with respect to $x$, a focal point in economics, is $\frac{\beta}{1-\alpha}$ regardless of whether frictional growth is zero or not. It is this fact, we believe, which has led economists to disregard the role of frictional growth in macroeconometric models. As we demonstrate below, although frictional growth does not affect single-equation unemployment rate models (and generally NRU models), it has major implications for dynamic multi-equation labour market models.

Without loss of generality, let us analyse one of the simplest cases of multi-equation labour market models where frictional growth can arise. Consider the following AR(1) labour demand and static labour supply equations, each featuring a single exogenous variable:

$$
\begin{aligned}
n_{t} & =\alpha_{1} n_{t-1}+\beta_{1} k_{t}, \\
l_{t} & =z_{t},
\end{aligned}
$$

where $n_{t}$ denotes employment, $l_{t}$ is labour force, $k_{t}$ is capital stock, $z_{t}$ is working age population, the autoregressive parameter is $0<\alpha_{1}<1$, and $\beta_{1}$ is a positive constant. ${ }^{8}$ All variables are in logs; we ignore the error terms for ease of exposition.

The unemployment rate (not in logs), can be approximated by the difference between the labour force and employment:

$$
u_{t}=l_{t}-n_{t} .
$$

This definition implies that the unemployment rate stabilises in the long-run, i.e. $\Delta u^{L R}=0$, when $\Delta l^{L R}=\Delta n^{L R}$. In other words, for unemployment stability in the long-run, the growth

\footnotetext{
${ }^{8}$ Observe that when all variables are $\mathrm{I}(1)$, the labour demand and supply equations (5)-(6) imply the cointegrating vectors $\left(1,-\beta_{1} /\left(1-\alpha_{1}\right)\right),(1,-1)$, respectively.
} 
rate of employment should be equal to the growth rate of the labour force, say $g .{ }^{9}$ This restriction can also be expressed in terms of the long-run growth rates of the exogenous variables:

$$
\Delta n^{L R}=\Delta l^{L R}=g \Leftrightarrow \frac{\beta_{1}}{1-\alpha_{1}} \Delta k^{L R}=\Delta z^{L R}=g .
$$

We refer to (8) as the frictional growth $(F G)$ stability condition, since it ensures that the unemployment rate stabilises in the long-run.

Next, reparameterise labour demand (5) as

$$
n_{t}=\frac{\beta_{1}}{1-\alpha_{1}} k_{t}-\frac{\alpha_{1}}{\left(1-\alpha_{1}\right)} \Delta n_{t}
$$

and subtract it from the supply equation (6) to obtain the following unemployment dynamics:

$$
u_{t}=\underbrace{\left(z_{t}-\frac{\beta_{1}}{1-\alpha_{1}} k_{t}\right)}_{\text {"trend" }}+\underbrace{\frac{\alpha_{1}}{1-\alpha_{1}} \Delta n_{t}}_{\substack{\text { "cycle" if long-run growth }=0 \\ \text { "frictional growth" otherwise }}} .
$$

Observe that, similarly to the $\mathrm{AR}(1)$ equation (4), the term in parentheses captures the "trend" of the unemployment rate and the second term describes its cyclical variations if employment and labour force are not growing in the long run. If, on the other hand, employment and labour force have nonzero long-run growth rates (due to the growing capital stock and working-age population), the second term generates frictional growth.

Under the frictional growth (FG) stability condition (8), the long-run solution of the above is:

$$
u^{L R}=\underbrace{\left(z^{L R}-\frac{\beta_{1}}{1-\alpha_{1}} k^{L R}\right)}_{\text {NRU }}+\underbrace{\frac{\alpha_{1} \beta_{1}}{\left(1-\alpha_{1}\right)^{2}} \Delta k^{L R}}_{\text {frictional growth }},
$$

where the first term in parentheses measures the NRU (the steady-state) and the second term captures frictional growth, i.e. the interplay between growth and the employment adjustment process. Note that, although working-age population and capital stock are growing variables, unemployment rate is trendless in the long run due to the FG stability condition (8).

The long-run value $\left(u^{L R}\right)$, towards which the unemployment rate converges, reduces to the NRU only when frictional growth is zero - i.e. either when the exogenous variables do not grow or when the labour demand and supply equations have identical dynamic structures (in this example when both labour demand and supply are static equations). Therefore, frictional growth implies that the NRU ceases to serve as an attractor for the unemployment

\footnotetext{
${ }^{9}$ Note that the growth rate of $\log$ variables is proxied by their first differences, $\Delta(\cdot)$. We can plausibly assume that both capital stock and working-age population are growing variables with growth rates that stabilise in the long-run.
} 
rate and questions its relevance in policy making. Another implication of frictional growth is that unemployment cannot be simply reduced into the sum of "trend" and "cyclical" components.

Obviously, frictional growth does not feature in studies which (i) examine dynamic singleequation models (such as Nickell, Nunziata and Ochel, 2005), since there are no interactions, or (ii) use static models (such as Nickell, 1997; and Blanchard and Wolfers, 2000), since labour market dynamics are simply sidelined.

We should emphasize that one of the salient features of the CRT models, is that, in contrast to single-equation NRU models, they can also include growing exogenous variables. The only requirement is that each equation is balanced (i.e. dynamically stable) so that each growing dependent variable is driven by the set of its growing determinants. It can be shown that equilibrating mechanisms in the labour market and other markets jointly act to ensure that the unemployment rate is trendless in the long-run (Karanassou and Snower, 2004). In terms of the above analytical model, these mechanisms can be expressed in the form of the FG stability condition (8). In short, CRT models generate frictional growth which implies that, since

$$
\text { long-run }=\underset{(\text { steady-state })}{\mathrm{NRU}}+\text { frictional growth, }
$$

(i) unemployment may substantially deviate from its natural rate, and

(ii) it cannot be decomposed into "trend" and cyclical components.

Due to our limited knowledge of the long-run growth rates of the exogenous variables we cannot obtain reliable estimates of frictional growth, and consequently of the long-run unemployment rate. Therefore, CRT models do not aim at evaluating the natural (or longrun) unemployment rate, but, instead, focus on the contributions of the exogenous variables to the evolution of the unemployment rate (see Section 5).

\subsection{Unemployment Determinants in a CRT Model}

We illustrate the analytical workings of the CRT by adding a wage setting equation to the simple model (5)-(6) of the previous section, and by introducing spillover effects in the labour demand and wage setting equations:

$$
\begin{aligned}
n_{t} & =\alpha_{1} n_{t-1}+\beta_{1} k_{t}-\gamma_{1} w_{t} \\
w_{t} & =\alpha_{2} w_{t-1}+\beta_{2} b_{t}-\gamma_{2} u_{t}, \\
l_{t} & =z_{t}
\end{aligned}
$$

where $n_{t}$ is employment, $w_{t}$ is real wage, and $l_{t}$ is labour force, $u_{t}$ is the unemployment rate $k_{t}$ is real capital stock, $b_{t}$ is real benefits, and $z_{t}$ is working-age population; the $\beta$ 's and $\gamma$ 's 
are positive constants, and $0<\alpha_{1}, \alpha_{2}<1$. As in the previous section, all variables except unemployment are in logs and we ignore the error terms for simplicity.

In the context of the above model, a number of important remarks are to be made.

1. The autoregressive parameters capture the employment adjustment and wage/price staggering effects, respectively.

2. The $\gamma$ 's generate spillover effects, since changes in an exogenous variable in one equation, say working-age population in labour supply, can also affect the real wage (by feeding through $u_{t}$ ) and, in turn, labour demand (by feeding through $w_{t}$ ). Observe that when $\gamma_{1}$ and $\gamma_{2}$ are both nonzero, all labour market shocks generate spillover effects. If $\gamma_{2}=0$, i.e. if unemployment does not put downward pressure on wages, then labour demand and supply shocks do not spillover to wages. Note that the main feedback mechanism in this model is provided by the wage elasticity of labour demand. If $\gamma_{1}=0$, i.e. if labour demand is completely inelastic with respect to wages, then shocks to wage setting do not spillover to employment and unemployment. In this case, (i) benefits do not influence unemployment, and (ii) the unemployment effects of the exogenous variables $k_{t}$ and $z_{t}$ can be adequately measured by individual analysis of the labour demand and supply equations, respectively.

3. In the presence of spillover effects, the individual labour demand and supply equations cannot provide adequate measures of the sensitivities of unemployment to the exogenous variables. We refer to the $\beta$ 's as the "local" short-run elasticities (i.e. the elasticities obtained simply by eye inspection) in order to distinguish them from the "global" ones, which incorporate all the feedback mechanisms in the labour market model. The global elasticities can be obtained by the univariate representation of unemployment, which expresses unemployment as a function of its own lags and the exogenous variables in the system.

It is worth noting that the empirical CRT model in the next section is an expanded version of the above stylised labour market model characterised by a variety of lagged adjustment processes and feedback mechanisms.

We now show how to derive the univariate representation of unemployment by rewriting the labour demand and real wage equations (12)-(13) as

$$
\begin{aligned}
\left(1-\alpha_{1} B\right) n_{t} & =\beta_{1} k_{t}-\gamma_{1} w_{t}, \\
\left(1-\alpha_{2} B\right) w_{t} & =\beta_{2} b_{t}-\gamma_{2} u_{t},
\end{aligned}
$$

where $B$ is the backshift operator. Substitution of (16) into (15) gives

$$
\left(1-\alpha_{1} B\right)\left(1-\alpha_{2} B\right) n_{t}=\gamma_{1} \gamma_{2} u_{t}+\left(1-\alpha_{2} B\right) \beta_{1} k_{t}-\gamma_{1} \beta_{2} b_{t}
$$


Next, rewrite the labour supply (14) as

$$
\left(1-\alpha_{1} B\right)\left(1-\alpha_{2} B\right) l_{t}=\left(1-\alpha_{1} B\right)\left(1-\alpha_{2} B\right) z_{t} .
$$

Finally, use definition (7) and subtract labour demand (17) from labour supply (18) to obtain the univariate representation (or reduced form) of the unemployment rate equation:

$$
\left[\gamma_{1} \gamma_{2}+\left(1-\alpha_{1} B\right)\left(1-\alpha_{2} B\right)\right] u_{t}=-\left(1-\alpha_{2} B\right) \beta_{1} k_{t}+\gamma_{1} \beta_{2} b_{t}+\left(1-\alpha_{1} B\right)\left(1-\alpha_{2} B\right) z_{t} .
$$

The term "reduced form" relates to the fact that the parameters of the equation are not estimated directly, instead, they are some nonlinear function of the parameters of the underlying labour market system (12)-(6). ${ }^{10}$ Alternatively, the unemployment rate equation (19) can be written as

$$
u_{t}=\phi_{1} u_{t-1}-\phi_{2} u_{t-2}-\theta_{k} k_{t}+\theta_{b} b_{t}+\theta_{z} z_{t}+\theta_{k} \alpha_{2} k_{t-1}-\phi_{1} z_{t-1}+\phi_{2} z_{t-2}
$$

where $\phi_{1}=\frac{\alpha_{1}+\alpha_{2}}{1+\gamma_{1} \gamma_{2}}, \phi_{2}=\frac{\alpha_{1} \alpha_{2}}{1+\gamma_{1} \gamma_{2}}, \theta_{k}=\frac{\beta_{1}}{1+\gamma_{1} \gamma_{2}}, \theta_{b}=\frac{\gamma \beta_{2}}{1+\gamma_{1} \gamma_{2}}$, and $\theta_{z}=\frac{1}{1+\gamma_{1} \gamma_{2}}$.

The above reduced form unemployment rate equation (20) displays the following characteristics of the CRT. The autoregressive coefficients $\phi_{1}$ and $\phi_{2}$ embody the interactions of the employment adjustment $\left(\alpha_{1}\right)$ and wage-price staggering $\left(\alpha_{2}\right)$ processes. The $\theta$ 's embody the feedback mechanisms built in the system, since they are a function of the slope coefficients ( $\beta$ 's) of the individual equations (12)-(14) and the spillovers $(\gamma$ 's). Thus, the $\theta$ 's describe the "global" short-run sensitivities of unemployment with respect to the exogenous variables. The interplay of dynamics across equations is further emphasized by the lagged structure of the exogenous variables. Using time series jargon, we refer to the lagged exogenous variables as "moving-average" terms.

Observe the difference between the "local" and "global" sensitivities of unemployment. For example, while the "local" short-run semi-elasticity of the unemployment rate with respect to capital stock is $\beta_{1}$ (by equations (12) and (7)), its "global" short-run elasticity is $\frac{\beta_{1}}{1+\gamma_{1} \gamma_{2}}$ (by equation (20)). Generally, the plethora of spillovers in the system may render the local elasticities unreliable, since they might affect both their sign and size. The CRT approach takes this fact into account and uses the global sensitivities of the unemployment rate, as opposed to the local ones, to diagnose the economic plausibility of the labour market system.

As we already discussed in Section 3.2, a key element of the CRT is that capital stock, a trended variable, influences the time path of the unemployment rate, a stationary variable.

\footnotetext{
${ }^{10}$ The above equation is dynamically stable (i.e. balanced) since (i) products of polynomials in $B$ which satisfy the stability conditions are stable, and (ii) linear combinations of dynamically stable polynomials in $B$ are also stable.
} 
In the context of our stylised labour market model we can justify this result as follows. First, capital stock enters the system as a determinant of employment, a trended variable. Labour demand (12) is a balanced equation since it is dynamically stable $\left(\left|\alpha_{1}\right|<1\right)$. Second, the trended labour force is driven by working-age population (also a trended variable), and the static labour supply (14) is itself a balanced equation. Third, the labour demand equation remains balanced once the wage (13) has been substituted into it (see equation (17)). As a result, the derived unemployment rate equation ((19) or (20)) is itself dynamically stable, since it is obtained by the difference of two dynamically stable equations (i.e. labour supply and demand).

The detailed interplay between dynamics and growth, and the interactions among the various lagged adjustment processes portrayed in the CRT model cannot be captured by a single-equation NRU model. In other words, estimating a single unemployment rate equation is not equivalent to estimating a multi-equation labour market system. Karanassou, Sala and Snower (2003) show that if a single-equation NRU model, and each equation of a CRT model, which comprises labour supply and demand equations, have all identical regressors, then the two estimation procedures will yield identical results. However, in structural labour market systems, it is highly unlikely that each constituent equation will have the same regressors, and so the single-equation model cannot be viewed as an unbiased summary of the CRT multi-equation model.

\section{$4 \quad$ Estimated Equations}

In the spirit of the above stylised CRT model, we estimate a dynamic multi-equation labour market system with spillovers comprising labour demand, labour supply and wage setting equations. As already noted in Section 2, our estimation technique is the ARDL approach to cointegration analysis, which is also used in Lewis and MacDonald (2002) and in most other CRT studies.

We should emphasize that the selected equations are dynamically stable and pass the standard misspecification tests (for linearity, structural stability, no serial correlation, homoskedasticity, and normality) at conventional significance levels. In addition, we estimate our equations as a system using 3SLS in order to take into account the potential endogeneity and cross equation correlation. In what follows we present our results and provide an overall evaluation of the empirical labour market model.

\subsection{Data}

We use annual data running from 1970 to 2006. All time series were obtained from the OECD Economic Outlook except for the ASX 200 stock market index (source: Bloomberg), 
and government expenditures (source: IMF International Financial Statistics). Table 1 gives the definitions of the variables in the selected specifications of the estimated equations.

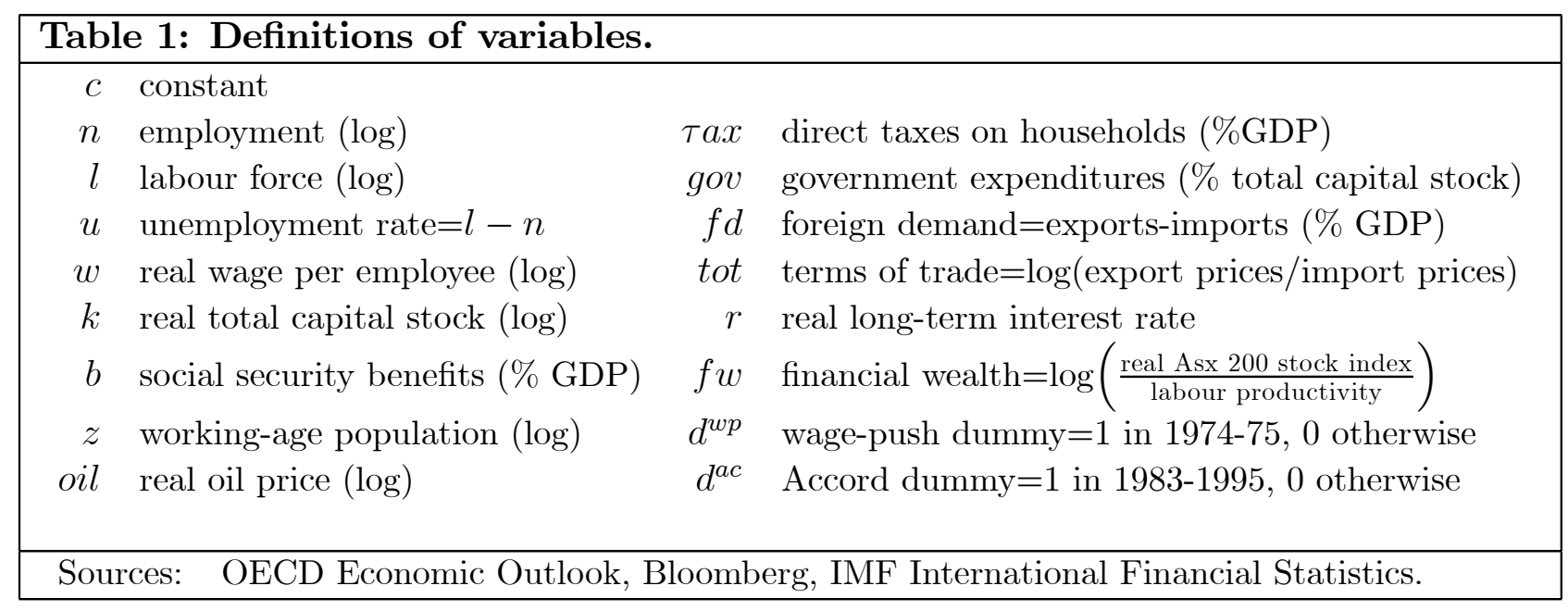

Most of our variables are quite standard, but some deserve further clarification. Financial wealth, for example, is defined as the Asx 200 stock index expressed in real terms and normalised by labour productivity. This follows Phelps and Zoega (2001) who argue that the swings in economic activity are influenced by the firm's expectations about future productivity, and proxy the latter by using the financial wealth variable. $d^{w p}$ is a wage-push dummy for the wage rise of 1974-75, aiming at an equal pay for women across occupational groups. The accord dummy $d^{a c}$, in turn, captures the effect of (i) the wage-pause that took place in 1983, and (ii) the "Prices and Incomes Accord" (i.e. the system of wage bargaining at a national level), which was implemented from the third trimester of 1983 until the mid 1990s with the aim to prevent excessive wage growth. We use the wage-push and Accord dummies in the wage-setting equation, following Pissarides (1991) who argued that they capture the income policies' effects on wages (see Section 5 for details).

\subsection{Labour Demand}

The labour demand equation contains a large set of determinants including supply- and demand-side factors, and external influences (see Table 2). The low persistence coefficient (measured by the sum of the autoregressive coefficients) of 0.19 , indicates quick employment adjustments to market shocks. Note that our selected equation includes the first two (annual) lags of employment, which is consistent with the dynamic structure of Lewis and MacDonald (2002) of seven quarterly lags. This is in contrast to Pissarides' (1991) finding of two quarterly lags and a much higher persistence coefficient of around 0.70 .

The first subset of determinants reflects (mainly supply-side) fundamentals and includes wages, interest rates and capital stock (Pissarides, 1991; Webster, 2003). The long-run elasticity of employment with respect to wages is -0.15 , which is in the lower range of the estimates given by Webster (2003) for Australia (between -0.15 to -0.8). This is in contrast to 
the -0.6 estimate given by Lewis and MacDonald (2002) who use output, rather than capital stock, as an explanatory variable. We find that the long-run elasticity of employment with respect to capital stock is 0.56 . For Australia, the scarce evidence on this value is mixed. Pissarides (1991) finds it very close to 1 so that he can safely restrict it to be unity, a value which is consistent with an underlying Cobb-Douglas production function. In contrast to Pissarides (1991), Rowthorn (1999) places the elasticity of substitution between capital and employment at (i) 0.77 using Bean, Layard and Nickell's (1986) study, (ii) 0.59 using Newell and Simon's (1985) estimates, and (iii) 0.62 using the LNJ (1991) results. The elasticity of substitution predicted by our model is consistent with the latter two.

\begin{tabular}{|c|c|c|c|c|c|}
\hline \multicolumn{3}{|c|}{ OLS } & \multicolumn{3}{|c|}{$3 \mathrm{SLS}$} \\
\hline & Coeff. & P-value & & Coeff. & $\mathrm{P}$-value \\
\hline$c$ & 7.07 & {$[0.000]$} & $c$ & 6.97 & {$[0.000]$} \\
\hline$n_{t-1}$ & 0.19 & {$[0.038]$} & $n_{t-1}$ & 0.20 & {$[0.004]$} \\
\hline$\Delta n_{t-1}$ & 0.58 & {$[0.000]$} & $\Delta n_{t-1}$ & 0.58 & {$[0.000]$} \\
\hline$w_{t}$ & -0.12 & {$[0.064]$} & $w_{t}$ & -0.11 & {$[0.037]$} \\
\hline$\Delta w_{t}$ & 0.18 & {$[0.016]$} & $\Delta w_{t}$ & 0.10 & {$[0.106]$} \\
\hline$r_{t}$ & -0.29 & {$[0.017]$} & $r_{t}$ & -0.24 & {$[0.015]$} \\
\hline$\Delta r_{t}$ & 0.27 & {$[0.019]$} & $\Delta r_{t}$ & 0.26 & {$[0.003]$} \\
\hline$k_{t}$ & 0.45 & {$[0.000]$} & $k_{t}$ & 0.44 & {$[0.000]$} \\
\hline$f w_{t}$ & 0.01 & {$[0.042]$} & $f w_{t}$ & 0.01 & {$[0.031]$} \\
\hline$o i l_{t-1}$ & -0.01 & {$[0.025]$} & $o i l_{t-1}$ & -0.01 & {$[0.001]$} \\
\hline$t_{t o t}$ & 0.11 & {$[0.003]$} & $t_{o} t_{t}$ & 0.12 & {$[0.000]$} \\
\hline$f d_{t-1}$ & 0.39 & {$[0.010]$} & $f d_{t-1}$ & 0.44 & {$[0.000]$} \\
\hline gov $_{t}$ & 2.78 & {$[0.000]$} & $g_{o v}$ & 2.68 & {$[0.000]$} \\
\hline$\Delta$ gov $_{t}$ & -1.51 & {$[0.013]$} & $\Delta$ gov $_{t}$ & -1.58 & {$[0.000]$} \\
\hline \multirow{2}{*}{\multicolumn{2}{|c|}{$\begin{array}{r}\text { std. error } \\
R^{2}\end{array}$}} & 0.007 & \multirow{2}{*}{\multicolumn{2}{|c|}{$\begin{array}{r}\text { std. error } \\
R^{2} \\
\end{array}$}} & 0.007 \\
\hline & & 0.999 & & & 0.999 \\
\hline
\end{tabular}

The second subset of driving forces is also standard. Financial wealth, which Phelps and Zoega (2001) argue is crucial for explaining the long swings of the unemployment rate in the OECD countries, enters our equation significantly and with the expected positive sign. Higher oil prices hurt labour demand and better terms of trade increase employment.

Finally, in line with Pissarides (1991), we identify the following two demand-side influences, both with the expected sign: (i) net foreign demand (as percentage of GDP) increases employment, and (ii) government expenditures (normalised by capital stock) have a positive impact on labour demand. Note that foreign demand, oil prices and the terms of trade provide a rich set of external factors affecting the Australian labour market. Also, while 
Pissarides (1991) argues that detrending government expenditures by capital stock allows an evaluation in terms of business cycle effects, our reasoning is somewhat different. Controlling for capital stock, we are able to interpret the coefficient of government expenditures as its effect on employment net of crowding out effects on investment.

\subsection{Wage Setting}

The wage setting equation is pretty standard - real wages are determined by unemployment, capital deepening, and a set of institutional variables. The persistence coefficient is rather low at 0.25 , reflecting the quick adjustments to shocks that characterise the Anglo-Saxon labour markets.

\begin{tabular}{|c|c|c|c|c|c|}
\hline \multicolumn{3}{|c|}{ OLS } & \multicolumn{3}{|c|}{$3 \mathrm{SLS}$} \\
\hline & Coeff. & $\mathrm{P}$-value & & Coeff. & P-value \\
\hline$c$ & 5.00 & {$[0.000]$} & $c$ & 5.07 & {$[0.000]$} \\
\hline$w_{t-1}$ & 0.25 & {$[0.033]$} & $w_{t-1}$ & 0.24 & {$[0.032]$} \\
\hline$\Delta w_{t-1}$ & 0.34 & {$[0.002]$} & $\Delta w_{t-1}$ & 0.31 & {$[0.006]$} \\
\hline$\Delta u_{t}$ & -0.80 & {$[0.002]$} & $\Delta u_{t}$ & -0.63 & {$[0.024]$} \\
\hline$\Delta u_{t-1}$ & 0.42 & {$[0.237]$} & $\Delta u_{t-1}$ & 0.47 & {$[0.068]$} \\
\hline$k_{t}-n_{t}$ & 0.25 & {$[0.000]$} & $k_{t}-n_{t}$ & 0.26 & {$[0.000]$} \\
\hline$b_{t}$ & 1.09 & {$[0.044]$} & $b_{t}$ & 1.03 & {$[0.014]$} \\
\hline $\operatorname{tax}_{t}$ & 0.68 & {$[0.040]$} & $\operatorname{tax}_{t}$ & 0.74 & {$[0.019]$} \\
\hline$d^{w p}$ & 0.06 & {$[0.000]$} & $d^{w p}$ & 0.06 & {$[0.000]$} \\
\hline$d^{a c}$ & -0.05 & {$[0.000]$} & $d^{a c}$ & -0.05 & {$[0.000]$} \\
\hline stc & error & 0.016 & stc & . error & 0.016 \\
\hline & $R^{2}$ & 0.978 & & $R^{2}$ & 0.978 \\
\hline
\end{tabular}

Unemployment reflects labour market demand conditions, and puts downward pressure on wages through the change in, rather than the level of, the unemployment rate $\left(\Delta u_{t}\right)$. In turn, capital deepening $\left(n_{t}-k_{t}\right)$, which commonly proxies labour productivity, exerts the expected positive influence. The institutional variables (social security benefits, $b_{t}$, and direct taxes of households, $\operatorname{tax}_{t}$ ) and the dummy $d^{w p}$ appear as wage-push factors. On the other hand, the Accord dummy $d^{a c}$, displays the expected negative sign.

\subsection{Labour force}

As indicated by the large persistence coefficient of 0.86 , labour force decisions are very persistent. These decisions are determined by economic and demographic factors. 


\begin{tabular}{|c|c|c|c|c|c|}
\hline \multicolumn{3}{|c|}{ OLS } & \multicolumn{3}{|c|}{ 3SLS } \\
\hline & Coeff. & P-value & & Coeff. & $\mathrm{P}$-value \\
\hline$c$ & -0.28 & {$[0.020]$} & $c$ & -0.30 & {$[0.007]$} \\
\hline$l_{t-1}$ & 0.86 & {$[0.000]$} & $l_{t-1}$ & 0.86 & {$[0.000]$} \\
\hline$\Delta l_{t-1}$ & -0.18 & {$[0.126]$} & $\Delta l_{t-1}$ & -0.14 & {$[0.152]$} \\
\hline$u_{t}$ & -0.32 & {$[0.000]$} & $u_{t}$ & -0.31 & {$[0.000]$} \\
\hline$\Delta u_{t-1}$ & -0.37 & {$[0.000]$} & $\Delta u_{t-1}$ & -0.36 & {$[0.000]$} \\
\hline$w_{t}$ & 0.05 & {$[0.012]$} & $w_{t}$ & 0.05 & {$[0.004]$} \\
\hline$w_{t} * d^{a c}$ & 0.003 & {$[0.000]$} & $w_{t} * d^{a c}$ & 0.003 & {$[0.000]$} \\
\hline$z_{t}$ & 0.14 & $(*)$ & $z_{t}$ & 0.14 & $(*)$ \\
\hline \multirow[t]{2}{*}{ std. error } & & 0.004 & std. error & & 0.004 \\
\hline & $R^{2}$ & 0.999 & & $R^{2}$ & 0.999 \\
\hline \multicolumn{3}{|c|}{ (*) Restricted to unity. } & \multicolumn{3}{|c|}{ (*) Restricted to unity. } \\
\hline
\end{tabular}

On the economic side, there is a discouraged-worker effect so that the higher the unemployment rate the lower the incentives to participate in the labour market. We also find that the real wage has a positive (albeit mild) effect on labour supply, which is slightly reinforced when it interacts with the "Accord" dummy $\left(w_{t} * d^{a c}\right)$. In other words, the elasticity of labour force with respect to the real wage increased during the "Prices and Incomes Accord" period. This result is consistent with Lewis and Kirby (1988) who find that the labour supply curve shifted outwards with the accord. However, it is in contrast to Pissarides (1991) who argues that the income and substitution effects cancel, since there is no significant influence of wages on labour supply.

On the demographic side, labour supply depends on the working-age population with a long-run elasticity equal to unity (according to a Wald test). This implies that, for a given unemployment rate and real wage, all people within the working-age group will end up participating in the labour market (for example, at some point, students will enter the labour force).

\subsection{Model Diagnostics}

To validate our estimated labour market model we follow three main diagnostic avenues:

1. we plot the actual and fitted values of the unemployment rate and evidence the accuracy of the latter,

2. we use the Johansen procedure and find that the long-run solutions implied by the ARDL approach represent cointegrating vectors, and 
3. we compute the "global" (interactive) sensitivities of unemployment with respect to the exogenous variables and find that they display the expected signs.

The fitted values of our estimated model are obtained by solving for the unemployment rate in the estimated labour demand, wage setting, labour supply equations (3SLS estimates in Tables 2-4), and the unemployment definition (7). Figure 1 plots the actual and fitted values and shows that our estimation tracks the data very well. We should emphasize that it is more difficult to obtain a good fit with a multi-equation labour market system than with a single unemployment rate equation. This is due to the numerous feedback mechanisms among the endogenous variables which are activated when we solve the model for the unemployment rate.

Figure 1. Unemployment rate: actual and fitted values

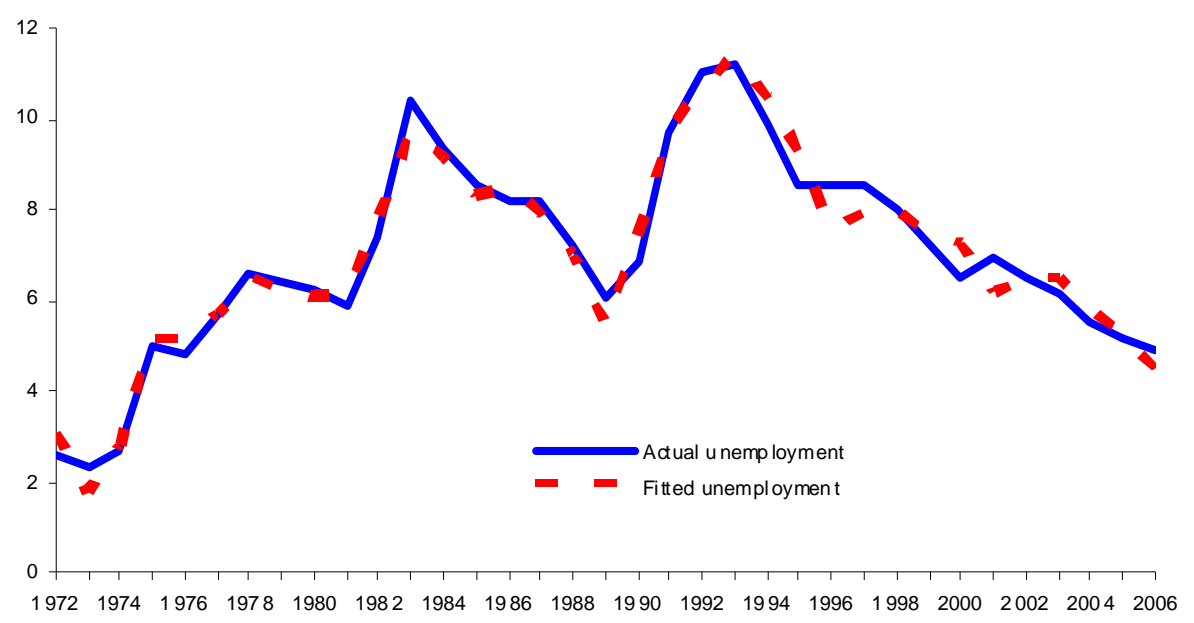

The second diagnostic deals with the long-run relationships of labour demand, wage setting and labour supply, which we estimated by applying the ARDL approach to cointegration analysis (second column in Table 5). In particular, we test whether they are significantly different from the cointegrating vectors obtained by the Johansen procedure (see also Lewis and MacDonald, 2002). Once the maximal eigenvalue and trace statistics confirm that the variables involved in each equation are cointegrated, the Johansen's cointegrating vectors (third column in Table 5) are restricted to take the corresponding long-run values of our estimated equations. The last column in Table 5 displays the corresponding likelihood ratio (LR) tests, which confirm that our estimation procedure is consistent with the Johansen one. $^{11}$

\footnotetext{
${ }^{11}$ It should be noted that the VAR model underlying the Johansen procedure contains all the variables in our labour market model, both the $\mathrm{I}(0)$ and $\mathrm{I}(1)$ variables. Naturally, the cointegration tests, only consider the I(1) variables in our models: $n_{t}, w_{t}, l_{t}, k_{t}$, and $z_{t}$. This implies that we test two restrictions in the labour demand, wage setting, and labour suply equations. To conserve space, we do not report the results of the underlying unit root and cointegration tests. These are available upon request.
} 


\begin{tabular}{|c|c|c|c|c|c|c|c|}
\hline \multirow[b]{2}{*}{ Labour demand } & \multicolumn{3}{|c|}{ ARDL } & \multicolumn{3}{|c|}{ Johansen } & \multirow[t]{2}{*}{ LR test } \\
\hline & $(N$ & $w$ & $k)$ & $(N$ & $w$ & $k \quad)$ & \\
\hline OLS & $(-1$ & -0.15 & $5 \quad 0.56)$ & $(-1$ & $-0.0 \varepsilon$ & $0.52)$ & $\chi^{2}(2)=0.81[0.666]$ \\
\hline 3SLS & $(-1$ & -0.14 & $\begin{array}{ll}4 & 0.55\end{array}$ & & & & $\chi^{2}(2)=0.61[0.617]$ \\
\hline Wage setting & $(w$ & $k$ & $n)$ & $(w$ & $k$ & $n \quad)$ & \\
\hline OLS & $(-1$ & 0.33 & $-0.33)$ & $(-1$ & 0.27 & $-0.22)$ & $\chi^{2}(2)=0.23[0.889]$ \\
\hline 3SLS & $(-1$ & 0.34 & $-0.34)$ & & & & $\chi^{2}(2)=0.21[0.899]$ \\
\hline Labour force & $(L$ & $w$ & $z)$ & $(L$ & $w$ & $z)$ & \\
\hline OLS (URTD.) & $(-1$ & 0.05 & $1.19)$ & $(-1$ & -0.05 & $1.22)$ & $\chi^{2}(2)=2.58[0.275]$ \\
\hline $3 \mathrm{SLS}=\mathrm{RTD}$ OLS & $(-1$ & 0.36 & $1.00)$ & & & & $\chi^{2}(2)=6.28[0.043]$ \\
\hline
\end{tabular}

Our final diagnostic tool is to compute the global (or interactive) long-run unemployment sensitivities to the exogenous variables (displayed in Table 6). The adjective "global" describes the fact that they incorporate all the spillover effects in the model, since they are the slopes/semi-elasticities of the univariate representation of the unemployment rate. The latter can be obtained by substituting the (3SLS) equations in Tables 2-4 into the unemployment definition (7) and solving for $u_{t}$ in terms of the exogenous variables. Then the long-run global sensitivities can be computed by the infinite sum of unemployment responses to an impulse (i.e. a one-off unit increase in the exogenous variable). ${ }^{12}$ The global long-run sensitivities offer a very effective way to decide on the economic plausibility of the empirical model. We believe that a major drawback of the traditional structural macroeconometric modelling has been its focus on the "local" sensitivities whose size and sign can be dramatically affected by the spillovers in the system.

\begin{tabular}{|ccccccccccccc|}
\hline \multicolumn{10}{|c|}{ Table 6: Global long-run unemployment rate sensitivities. } \\
\hline & $k$ & $r$ & $b$ & tax & gov & oil & tot & $f d$ & $f w$ & $z$ \\
\cline { 2 - 9 } & $\begin{array}{c}\text { Long run } \\
\text { sensitivity }\end{array}$ & -0.15 & 0.11 & 0.22 & 0.16 & -1.23 & 0.006 & -0.06 & -0.20 & -0.005 & 0.31 \\
\hline
\end{tabular}

Table 6 shows that the exogenous variables in our model influence unemployment in the expected way (for example, benefits increase it, government expenditures reduce it). Observe that, in contrast to conventional wisdom, capital stock puts downward pressure on unemployment even in the long run. Furthermore, when the above sensitivities are multiplied by the respective size of the shock (which is commonly measured by the sample standard deviation of the variable) they yield the long-run effect of each exogenous variable on the unemployment rate. ${ }^{13}$

\footnotetext{
${ }^{12}$ For details on this issue, see Karanassou and Sala (2008), and Karanassou, Sala and Snower (2009).

${ }^{13}$ For example, we find that a one-off rise of 4 percentage points in interest rates would increase (in the long-run) the unemployment rate by 0.44 percentage points (pp); a one-off $1 \%$ increase in capital stock causes
} 
Finally, the discussion in next section shows that our empirical model (Tables 2-4) follows the political events in Australia and takes into account the economic developments since the early 1970s.

\section{$5 \quad$ Economic and Political Developments}

In Australia, as in many OECD countries, the long post-war economic boom came to an end in the early 1970s. The economic model before the 1970s was characterised by substantial external protection (especially for the manufacturing sector) and public control of the financial, product and labour markets. Yet, the government was in the hands of the Liberal Party throughout the 1950s, 1960s and early 1970s. The first Labour government in 23 years was elected at the end of 1972 and attempted a Keynesian response to the crisis by increasing the rates of government spending (more inclusive social services, more responsive public sector). This pushed inflation upwards beyond its increase brought by the first oil price shock. However, this government stayed in power for just three years and its demise at the end of 1975 is considered as one of the most significant events in the Australian political history. A new administration of the Liberal Party came to power, lasting until 1983. Fiscal brakes where immediately implemented so as to improve public accounts, and measures to reduce wages and regain private sector confidence were introduced. While both governments were trying to manage the crisis through state intervention (albeit with opposing policies), none undertook any structural economic reforms. At the same time, the world economy was becoming progressively more interdependent and the Asian countries were entering the scene.

From 1983 to 1996 there were two Labour governments which, in contrast to the previous ones, were quite active in introducing economic reforms. ${ }^{14}$ The major one was the Prices and Incomes Accord, known as the 'Accord', which run from 1983 to 1996 and consisted of a set of wage setting arrangements under which unions committed to restrain their wage claims in exchange for other compensatory social provisions (in the form, for example, of selected tax cuts, superannuation awards or improvements in essential social services). The scope of the Accord was to create a more flexible system (which would be more focused on productivity performance), to modernise unions, and to bring a broad change in industrial relations (which would result in fewer disputes). Other reforms entailed administrative changes to enhance the efficiency of public services, removal of trade barriers (especially for the clothing, auto and wool industries), and also state-led reforms of central economic sectors. In addition, the banking sector opened to foreign companies.

From 1996 to 2007 the government was again in the hands of the Liberal party but this time it was coexisting with several Labour state governments, which spend more than $2 / 3$

the unemployment rate to fall by $5.55 \mathrm{pp}$ in the long run.

${ }^{14}$ It should be noted, though, that, as opposed to the pure liberalistation period of Howard's governments, the state played an active role in these reforms. 
of total public revenues. This was a period of comprehensive structural reforms fostering economic liberalisation. A first pilar was already setup in 1995, when Australia's nine state governments agreed on a so called National Competition Policy (NCP), which is considered as the most extensive economic reform programme in the history of Australia. At the public level, the NCP aimed at preventing an anti-competitive conduct of public enterprises, introducing tax reforms (for example the GST tax reform package) and, more recently, changing the funding and delivery arrangements for various government services at the public level. At the private level, the NCP aimed at further dismantling trade barriers and enhance the deregulation of the financial system. A second pilar was the removal of the Accord and the liberalisation of the labour market, while a third pilar was the reduction of government revenues in conjunction with a fiscal consolidation process (indeed, quite often during this period the government annual budget was in surplus). ${ }^{15}$

The economic and policy developments of these years are pictured in Figure 2 with the plots of the ten exogenous variables used in our model. Until the mid 1970s there was a rise in social security benefits and direct taxes (together with a temporary increase in government expenditures), which was followed by a sudden reduction in the second half of the 1970s (coinciding with the change of government in 1975). The period of the 1970s and early 1980s is characterised by the oil price shock, the increase in interest rates, and the deterioration of the terms of trade. In contrast, there was no significant variation in the trade surplus. Capital accumulation, financial wealth and the growth rate of working-age population experienced a sharp downturn in the beginning of the 1970s, but recovered afterwards and ended up in 1983 with similar values to those in 1973 .

During the marathon boom of the 1990s and 2000s, there was not much action on the institutional side (benefits and direct taxes), but there was a clear decline in government expenditures and a fall in interest rates. Financial wealth did not change much, despite its brief increase in the second half of the 1990s. Regarding the growth rate of working-age population, there was a clear acceleration after its sharp decline in the previous decade. Like the 1970s, oil prices were increasing but, in clear contrast to that period, there was a boom in the terms of trade. This was accompanied by a sharp erosion in the trade balance (as \% of GDP), which moved from a surplus close to $4 \%$ in the second half of the 1990s to a deficit of $4 \%$ in 2006. This dramatic performance of the external sector is one of the two salient features of the 1993-2006 period. The second one is the profound acceleration of capital accumulation - capital stock growth increased from around $2 \%$ in 1993 to $4 \%$ by the end of this period.

\footnotetext{
${ }^{15}$ O'Neill and Fagan (2006) survey the last three decades of economic reforms in Australia. The OECD Economic Surveys for Australia (1998, 1999, 2000, 2001, 2003, 2004 and 2006) provide detailed accounts of its developments with specific focus on the economic policy and the process of structural reforms.
} 
a. Capital accumulation

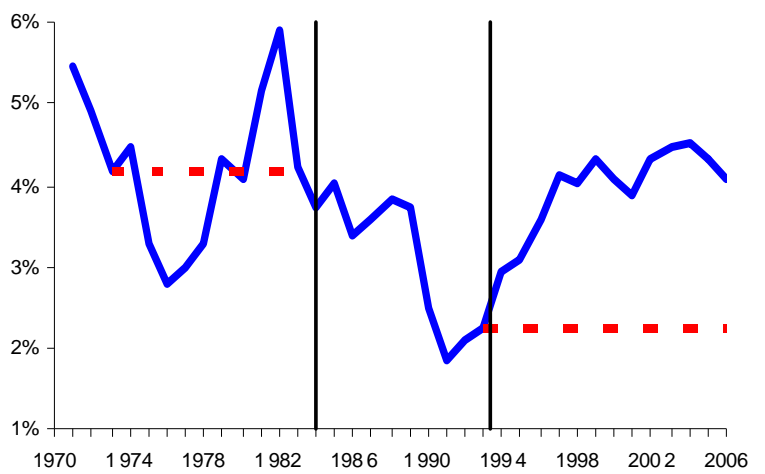

c. Social security benefits
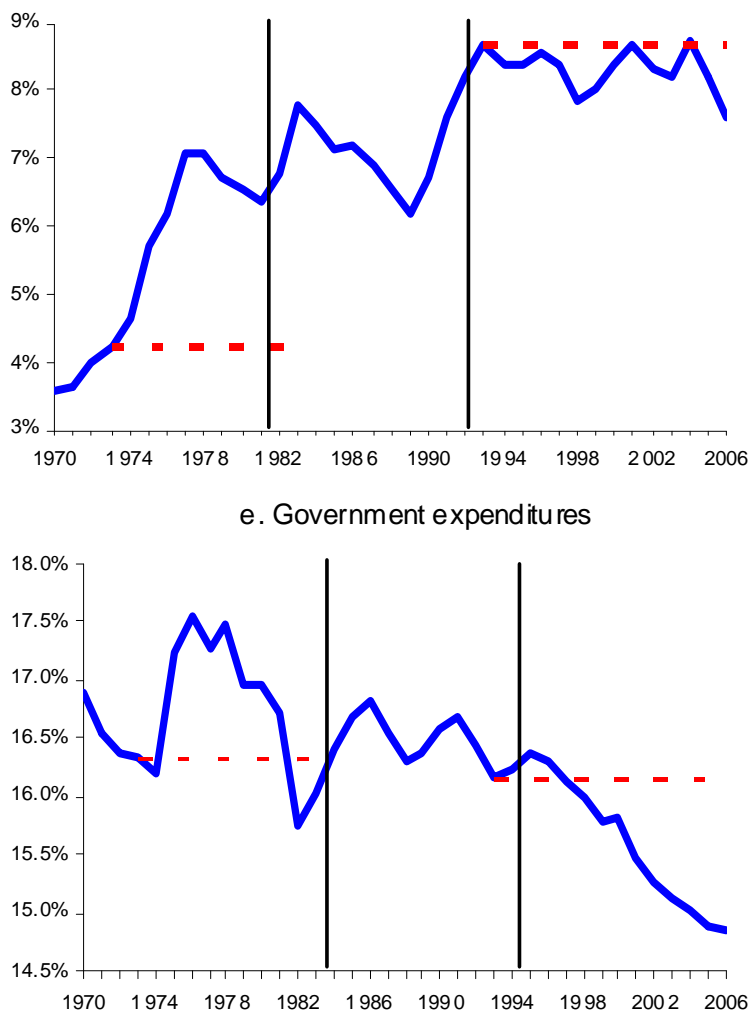

b. Real interest rates

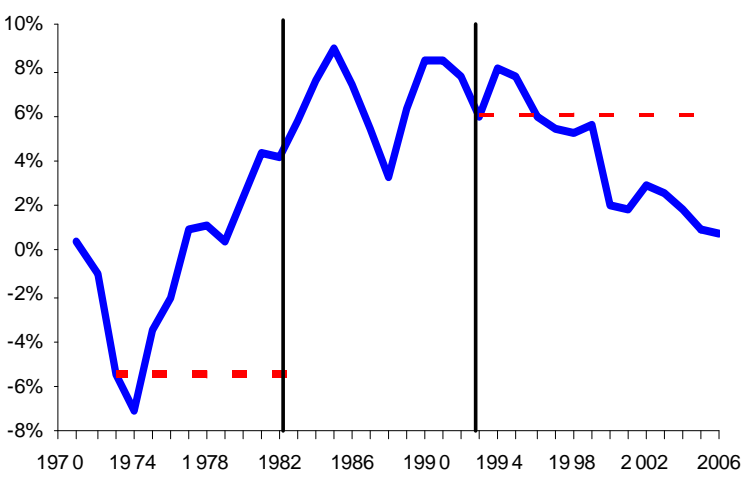

d. Direct taxes on households
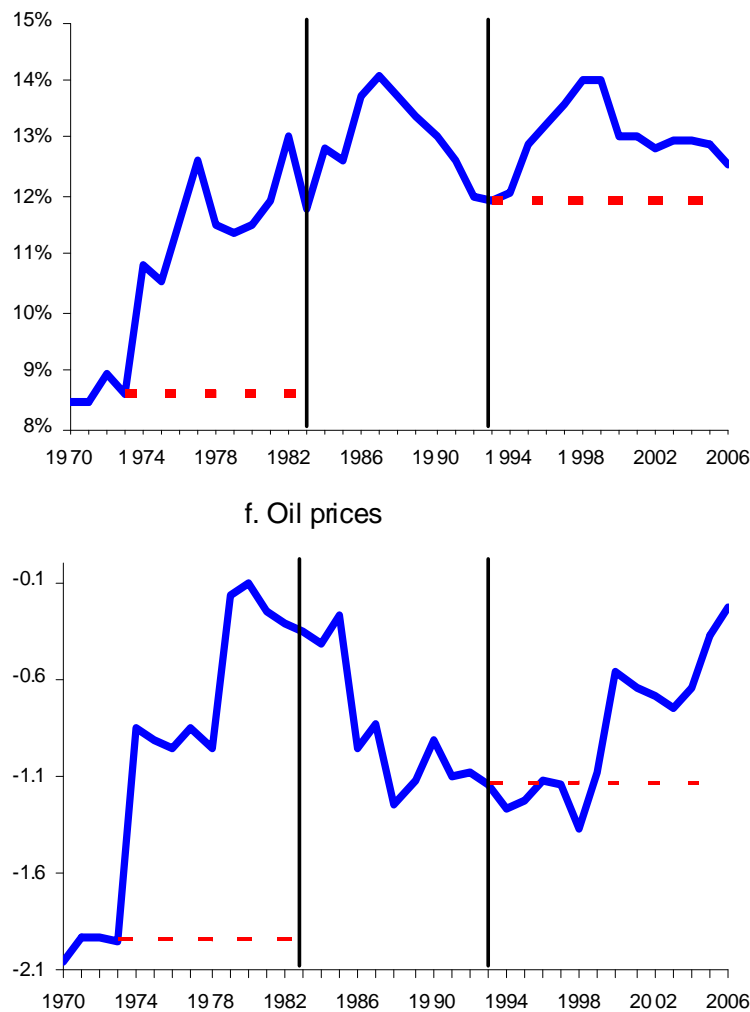

Regarding the external sector, the Australian 1993-2006 boom has been safeguarded by the performance of the Chinese economy. Indeed, Australia was not affected by the problems which two of its traditional partners were facing: the 1990s Japanese turmoil and the US downturn of the early 2000s. This was because (i) strong Chinese demand was pushing the prices of Australian raw materials relentlessly up (especially on iron ore, coal and aluminium), and (ii) China was a source of cheap imports (office supplies, appliances, toys), which implied lower costs for Australian factories and easily affordable consumer products. 
g. Terms of trade

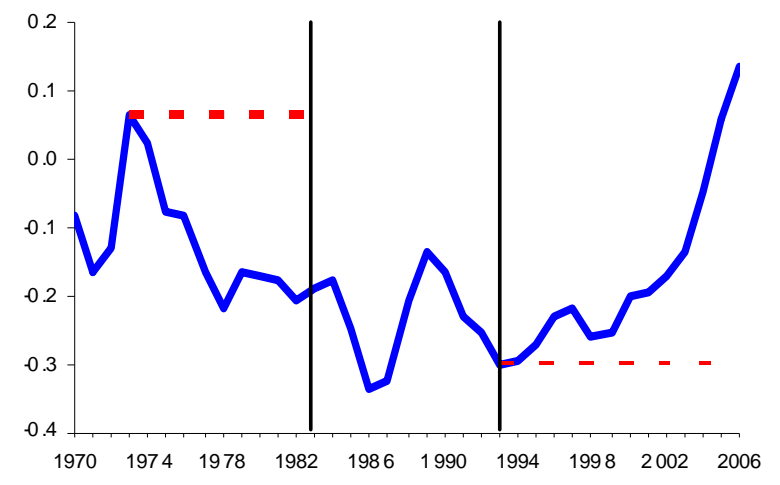

i. Financial wealth

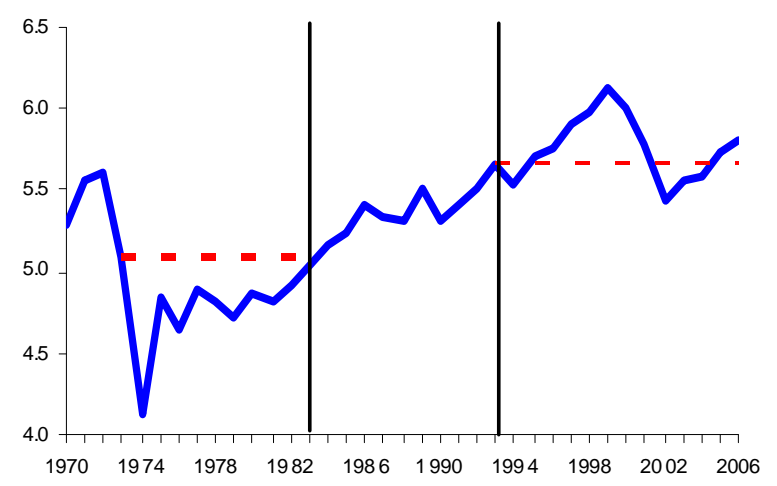

h. Foreign demand
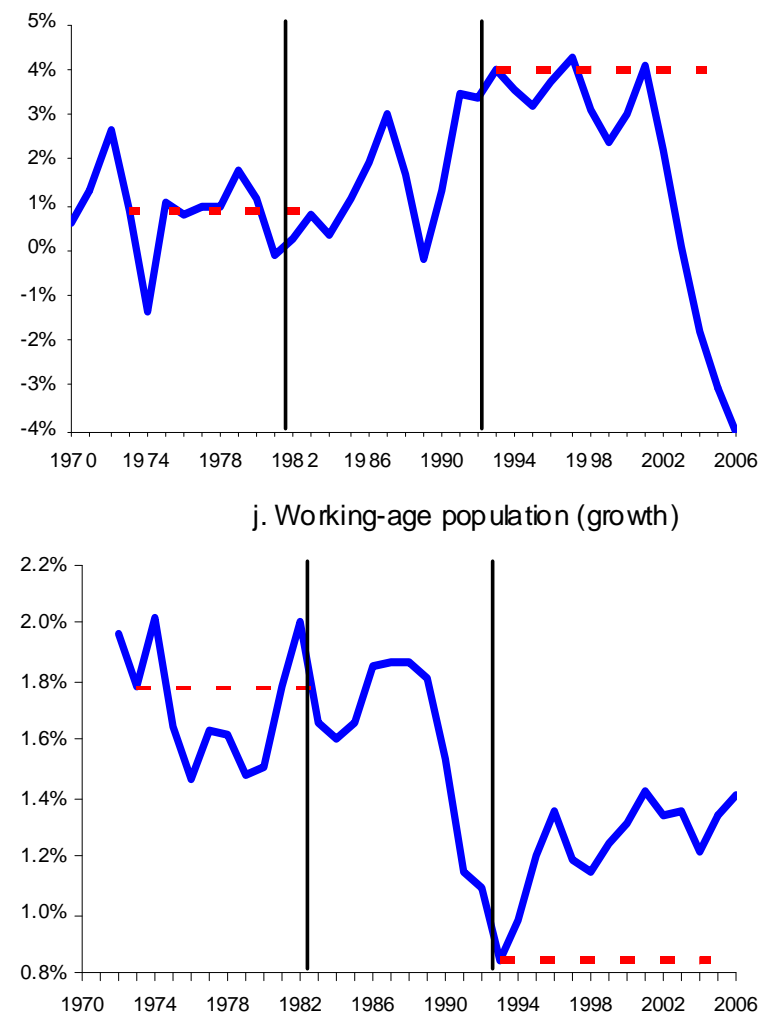

Regarding the acceleration in capital accumulation, Parham (2004) argues that it was important for the productivity revival in the 1990s. Although Parham (2004) acknowledges the link between the stellar productivity performance of Australia to its economic reforms (in line with the OECD Economic Surveys), he states that "The accumulation of physical and human capital has laid a long-term foundation for productivity growth." [p. 239] Over the 1950-1994 period, Madden and Savage (1998) find openness to trade and international competitiveness to be significant sources of Australian labour productivity in the short-run, but "in the longrun, fixed capital accumulation is the dominant source of productivity improvement." [p. $362]$

\section{Driving Forces of Unemployment}

In the context of the empirical CRT model of Section 4, we assess the driving forces of the labour market by evaluating the contribution of the exogenous variables to the evolution of unemployment during two periods of interest - the unemployment upturn in 1973-1983 and the unemployment decline in 1993-2006.

In each period we simulate the model (i.e. the 3SLS equations in Tables 2-4 and the unemployment definition (7)) under the counterfactual scenario that the exogenous variables are fixed (one at a time) at their 1973 or 1993 values. Figure 2 plots the actual series 
for the whole sample (solid lines) and their fixed values over the 1973-1983 and 1993-2006 periods (dotted lines). In turn, Figures 3 and 4 plot the trajectories of actual unemployment (solid lines) and the simulated unemployment rate (dotted lines) when each of the exogenous variables is kept constant at its 1973 and 1993 values, respectively. In this way, the dotted lines picture what would have been the unemployment trajectory had the given exogenous variable remained at the initial value of its time path, instead of having evolved as it actually did.

The dynamic contributions of the exogenous variables to the evolution of unemployment are then measured as the difference between its actual and simulated values. Therefore, the contribution of a given exogenous variable over a period of time represents how much would the unemployment rate have deviated from its actual value in the absence of any change in the variable. ${ }^{16}$

It is worth pointing out that the contribution of each exogenous variable reflects only its direct effect on unemployment, ceteris paribus, and does not capture any indirect effects through its possible influences on other exogenous variables in the model. The latter can be captured if all other exogenous variables were to be endogenised, which is beyond the scope of our work. We should also note that, although VAR models have the capacity of disentangling the effects of all variables, since they are all endogenous, they have the disadvantage of examining the effects of only generic one-off shocks instead of actual ones. Thus, the CRT methodology - due to the rich structure of endogenous and exogenous variables, network of spillovers, overall model diagnosis, and consideration of actual shocks and their unemployment contributions - has a comparative advantage in the empirical assessment of economic developments over VARs and traditional structural macroeconometric models. ${ }^{17}$

\section{$6.1 \quad 1973-1983$}

The unemployment rate increased by 8.1 percentage points $(\mathrm{pp})$ over this period, from $2.3 \%$ in 1973 to $10.4 \%$ in 1983. Our analysis is pictured in Figure 3 and shows that a variety of factors accounted for this rise, some of them being common in the macro-labour literature

We find that our set of institutional variables, i.e. direct taxes, benefits and the (wagepush and Accord) dummies, account for $2.2 \mathrm{pp}$ of the surge in unemployment (see Figure 3c). This is about $27 \%$ of the $8.1 \mathrm{pp}$ unemployment increase over this period. That is, in the absence of the upward trend of these variables in the 1970s and early 1980s, documented in Figures 2c-d, the unemployment rate would have reached $8.2 \%$ in 1983 , instead of the actual

\footnotetext{
${ }^{16}$ For the sake of brevity and clarity, the variables with rather negligible contributions are not shown in Figures 3 and 4. These are foreign demand and working-age population in the first period (1973-1983), institutions and oil prices in the second period (1993-2006), and financial wealth in both.

${ }^{17}$ See Karanassou and Sala (2008) for a discussion of the empirical methodologies of (structural) VARs, CRT and traditional structural macro models.
} 
$10.4 \%{ }^{18}$ Note that institutional (i.e. wage pressure) variables are conventionally blamed to be a key contributor to the rise in unemployment. For example, Gregory (2000) asserts that "My view is that large average real wage increases in Australia and most OECD countries during the mid 1970s were largely responsible for the rising unemployment rates over the following seven or eight years." [123], and Pissarides (1991) argues that about three quarters of the unemployment increase between 1970-73 and 1976-79 was due to equilibrium factors, in particular the rise in the fiscal wedge and unemployment benefits.

Two other standard determinants in the literature are commodity price and interest rate shocks. Our model captures the shocks in commodity prices through the fall in the terms of trade and the rise in oil prices. Figures 3e-f show that these account for a total of 2.9 pp of the unemployment rise (1.7 pp due to the deterioration of the terms of trade, and 1.2 pp due to the increase in oil prices), which is about one third of the unemployment increase during this period. The unemployment impact of the terms of trade has already received some attention in Australia (Gruen, 2006). Regarding interest rate shocks, we find that their contribution was to increase unemployment by $1.5 \mathrm{pp}$ (i.e. $18.5 \%$ of its $8.1 \mathrm{pp}$ rise). Had the real long-term interest rate not been rising between 1973 and 1983, as shown in Figure 2b, the unemployment rate would have ended the period at $8.9 \%$ rather than its actual $10.4 \%$ (see Figure 3b).

The above results show that changes in institutions, commodity prices, and interest rates account for $81.5 \%\left(=\frac{2.2+2.9+1.5}{8.1}\right)$ of the unemployment increase from 1973 to 1983 and, thus, are in line with the conventional wisdom that shocks and institutions (such as benefits and taxes) are responsible for high unemployment rates.

However, our model also unveils the role played by other factors, such as capital stock and government spending, which are quite often sidelined in the literature. In particular, observe that the decrease in capital stock growth in the second half of the 1970s (Figure 2a) was responsible for $1.1 \mathrm{pp}$, or $18 \%$, of the $6.0 \mathrm{pp}$ increase in unemployment from 1976 to 1980 (Figure 3a). The powerful influence of capital accumulation will become apparent in the next section, where we examine the 1993-2006 period. In terms of government expenditures, our findings demonstrate that had they not been reduced so dramatically in the early 1980s, unemployment would have been 1.9 pp lower than its 1983 actual value (Figure 3d). Furthermore, the relatively generous government spending during 1976-1980 led to a reduction in the unemployment rate of around $2 \mathrm{pp}$, on average. In view of these findings, we wonder whether the fiscal consolidation of the early 1980s came too soon, while other driving forces were still pushing unemployment upwards.

\footnotetext{
${ }^{18}$ In particular, benefits account for a rise of $0.6 \mathrm{pp}$, taxes for $0.5 \mathrm{pp}$, the wage-push dummy for $0.2 \mathrm{pp}$, and the Accord dummy for 0.9 pp. Since this dummy was implemented in the last year of the 1973-1983 period, the value 0.9 only refers to its effect in 1983 . That is, had the wage-pause and the Accord not taken place, unemployment would have been higher by $0.9 \mathrm{pp}$ in 1983 .
} 
Figure 3. Unemployment contributions, 1973-1983

a. Capital accumulation

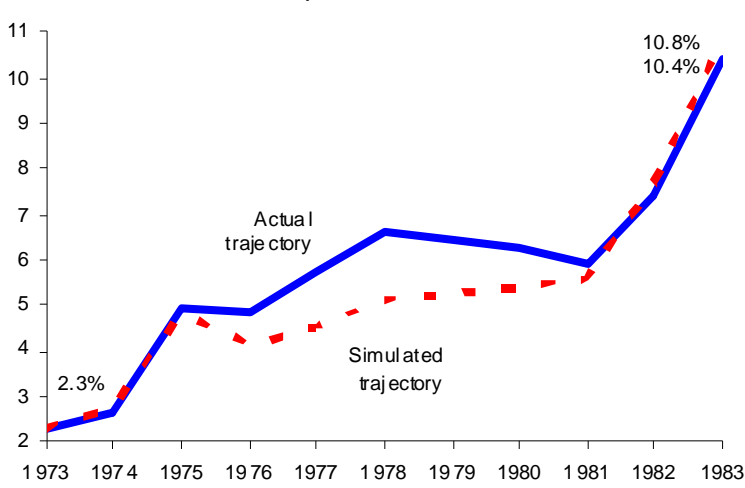

c. Institutional variables

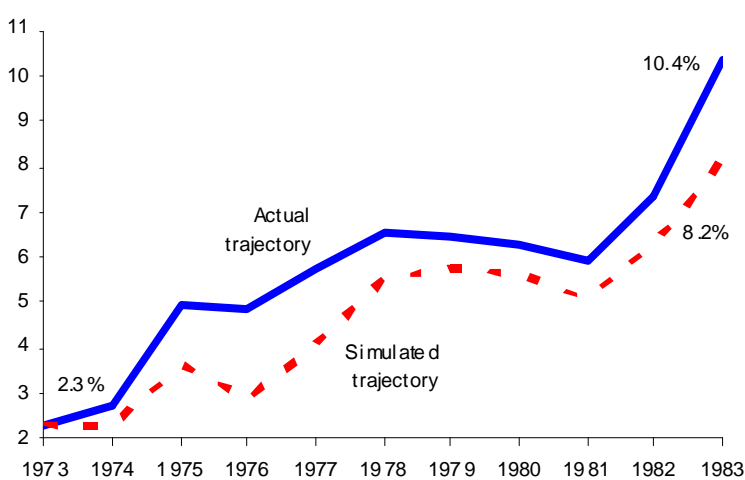

e. Terms of trade

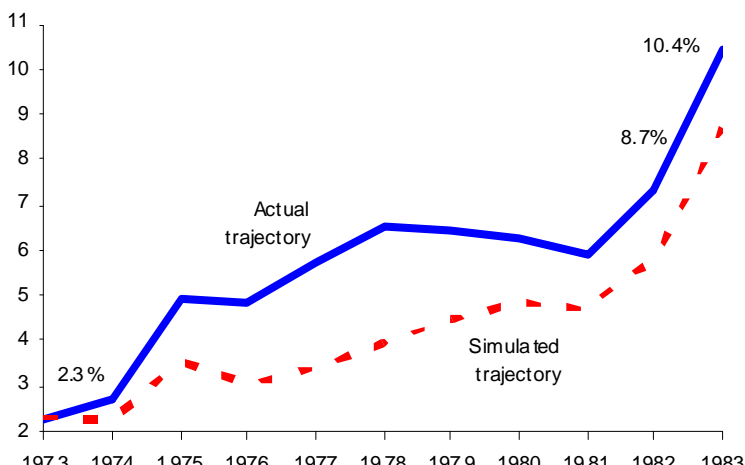

b. Real inte rest rates

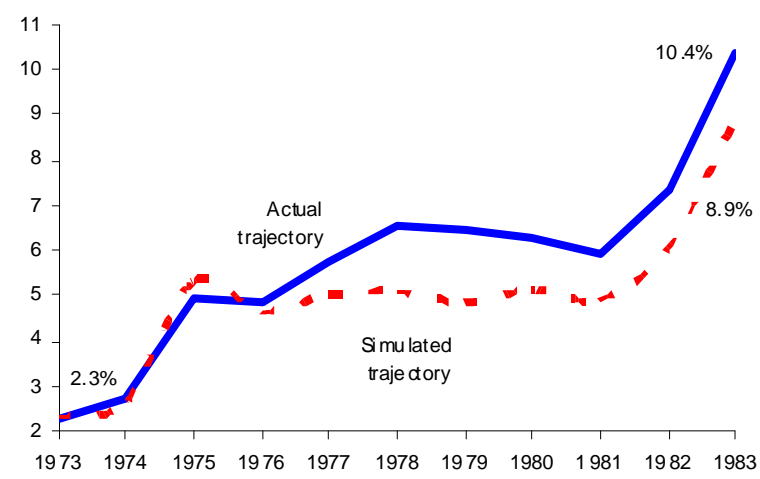

d. Government expenditures

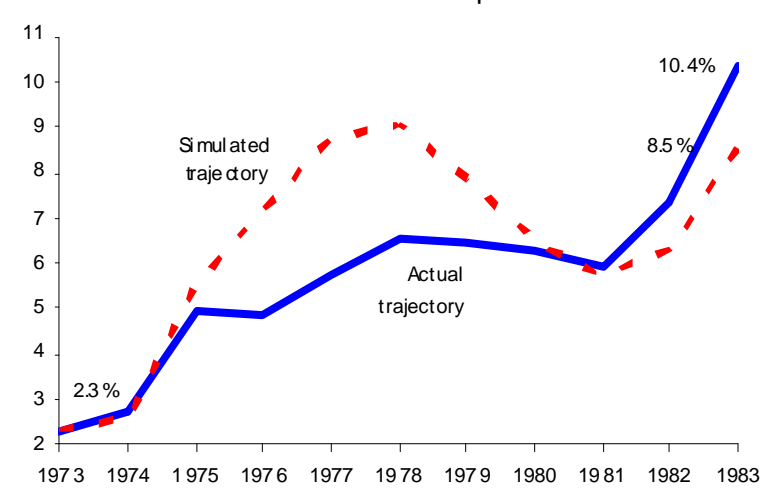

f. Oil prices

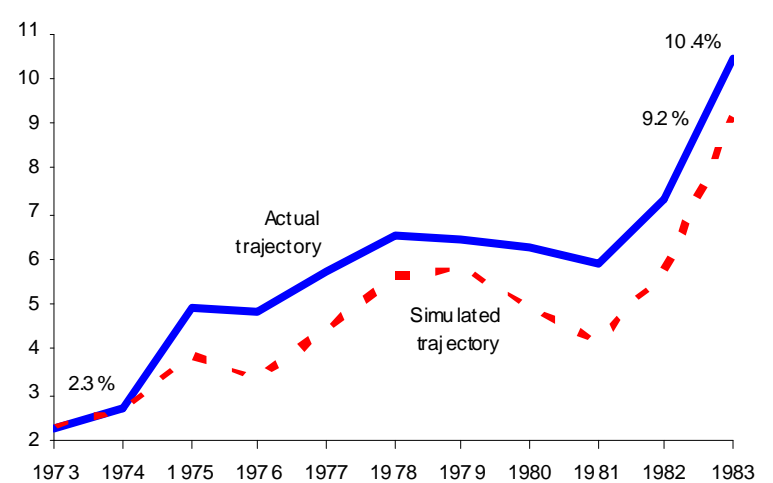

Note: Simulated trajectories result from fixing each exogenous variable at its 1973 value. Institutional variables comprise benefits, direct taxes, and the income policy dummies.

Although financial wealth and foreign demand affect significantly labour demand, and working-age population affects significantly labour supply, they had a minimal contribution to the trajectory of the unemployment rate from 1973 to 1983. For example, our simulations find that had financial wealth remained at its relatively high 1973 level (Figure 2i), unemployment would have ended up the period at $10.3 \%$ instead of its actual 10.4\%. In other words, financial wealth contributed to approximately only $1 \%$ of the rise in the unemployment rate during this period. This is in contrast to the studies of the structuralist theory advocates (e.g. 
Phelps and Zoega, 2001) who argue that financial wealth is the crucial driving force of the unemployment rate.

\section{$6.2 \quad 1993-2006$}

The unemployment rate declined by 6.3 pp during this period, from $11.2 \%$ in 1993 to $4.9 \%$ in 2006. Figure 4 displays the contributions of the exogenous variables to the fall in the unemployment rate. A central result of our analysis is that it distinguishes between the driving forces of the unemployment rate during the 1973-1983 and 1993-2006 periods.

First, capital accumulation contributed to reducing unemployment by 5.0 pp (Figure 4a). Had capital stock growth stayed constant at its 1993 value, unemployment would have been $9.9 \%$ in 2006 instead of its actual $4.9 \%$. The progressive increase in capital accumulation since the early 1990s (Figure 2a) was closely linked with much higher investment in new technologies, especially those associated with the ICTs and the 'new economy'. ${ }^{19}$ This sort of investment explains most of the increase in capital deepening (Banks, 2001) and is associated with the unprecedented period of rapid productivity growth in Australia, very much like the US one (see Parham, 2004). Increased international exposure also enhanced the performance of capital accumulation. In particular, the Australian Treasury (2006) reports that the recent terms of trade boom is being used by some export-oriented companies to invest and secure their advantageous international position. ${ }^{20}$

In addition, we find that the fall in interest rates (Figure $2 \mathrm{~b}$ ), which accompanied the acceleration of capital stock since the early 1990s, accounted for 0.7 pp reduction in the unemployment rate (Figure 4b). Note that this effect is on top of any potential influence of the interest rate on unemployment through capital accumulation (or another variable in the model). ${ }^{21}$

Second, although the impact of oil prices on unemployment in 1993-2006 was weaker than in 1973-1983 (0.5 pp and 1.2 pp contributions, respectively), the terms of trade factor became crucial for the Australian labour market. In particular, Figure 4e reveals that in the absence of the terms of trade boom, unemployment would have remained high, reaching $9.0 \%$ in 2006 , rather than its actual $4.9 \%$ (i.e. the terms of trade were responsible for $\frac{4.1}{6.3}=65 \%$ of the fall in unemployment). The extraordinary evolution of the terms of trade since 1999 (Figure $2 \mathrm{~g}$ ) resulted from a combination of cheap imports, mainly from China, and exports of raw materials (such as uranium, coal, nickel and other mineral resources) whose prices were on

\footnotetext{
${ }^{19}$ Investment in Information and Communication Technologies in Australia is part of a general restructuring process that has predominantly affected the wholesale, and the finance and insurance sectors.

${ }^{20}$ The links between capital accumulation and productivity growth are clearly beyond the scope of this paper. In other papers we have dealt with the impact of productivity on the labour market (see Agnese and Sala, 2009, for Japan; and Karanassou and Sala, 2008, for the US).

${ }^{21}$ To disentangle the direct and indirect (via capital stock) effects of the interest rate would require modelling capital stock as a function of the real interest rate, which is beyond the scope of this paper.
} 
the rise due to sustained increases in demand, again mainly from China (Australian Treasury, 2006).

Figure 4. Unemployment contributions, 1993-2006

a. Capital accumulation

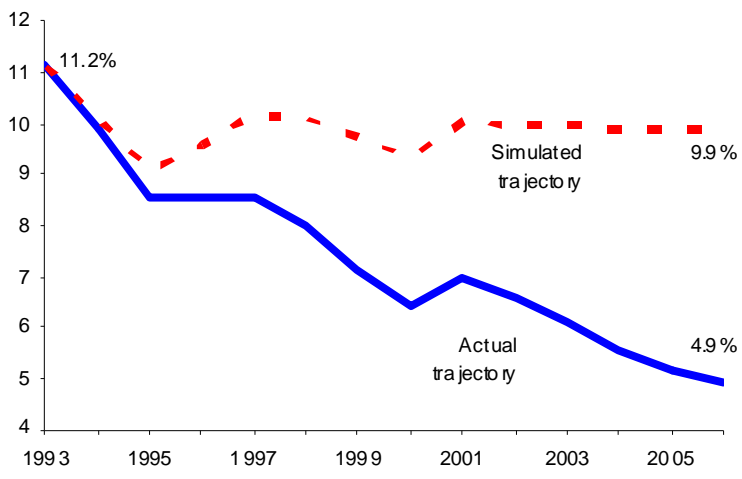

c. Prices and Incomes Accord

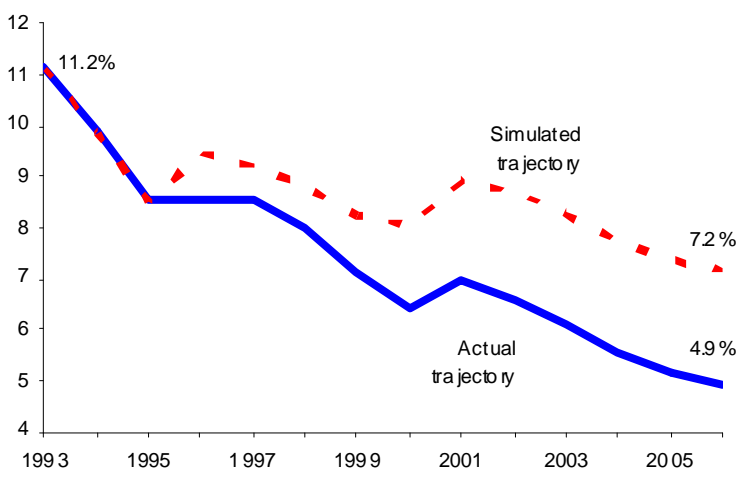

e. Terms of trade

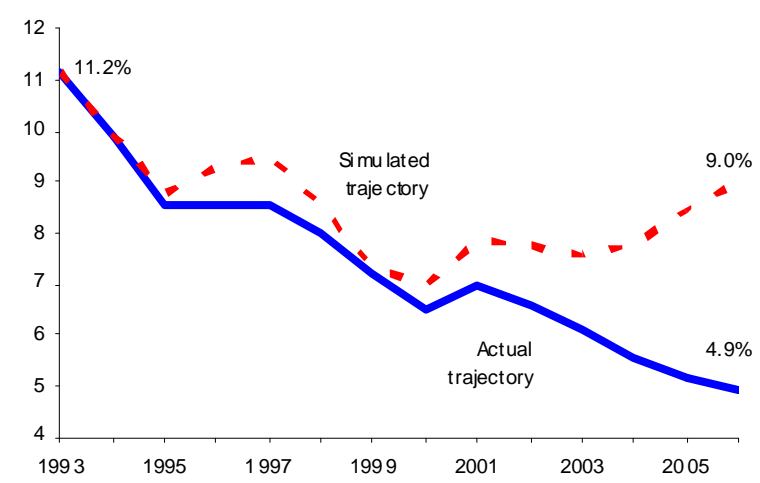

b. Real interest rates

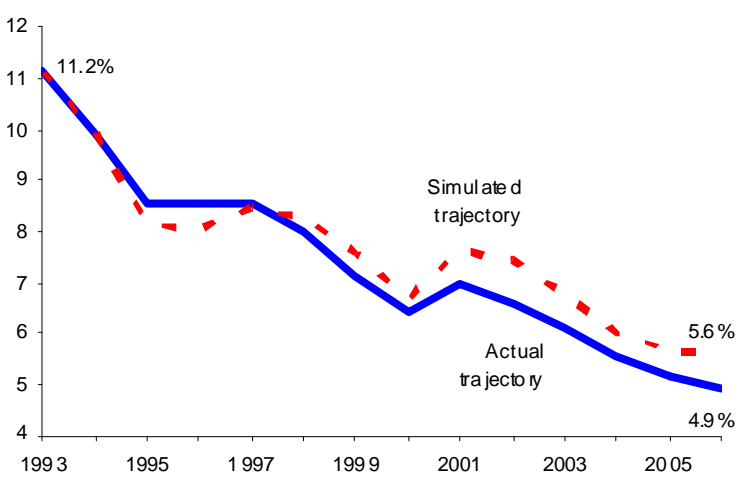

d. Government expenditures

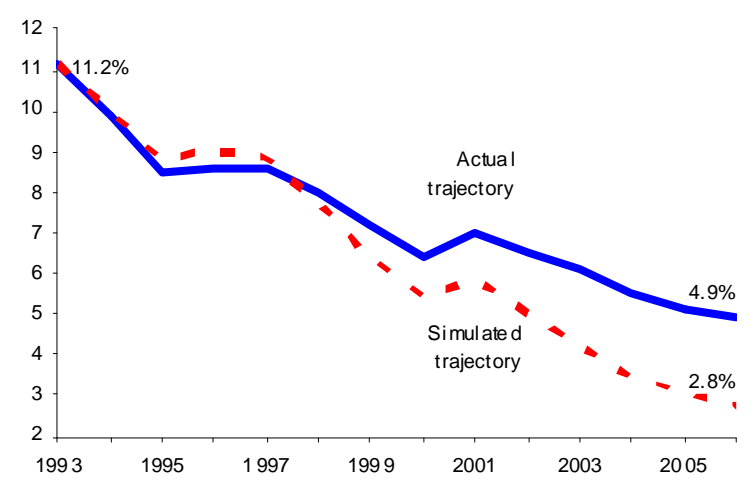

f. Foreign demand

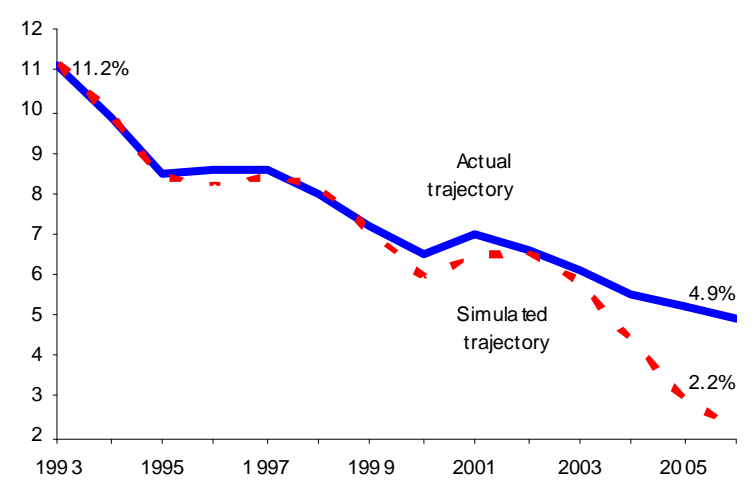

Note: Simulated trajectories result from fixing each exogenous variable at its 1993 value.

Third, regarding the external-related driving forces of Australian unemployment, foreign demand played a noticeable role in the evolution of unemployment only during the very recent years. In particular the fast deterioration of the trade balance in the 2000s (from a surplus of $4 \%$ in 2001 to a deficit of $4 \%$ in 2006) put substantial upward pressure on unemployment (see, respectively, Figures $2 \mathrm{~h}$ and $4 \mathrm{f}$ ), thus counteracting the terms of trade influence. Had 
foreign demand remained at its 1993 value, unemployment would have been lower by $2.7 \mathrm{pp}$ in 2006.

Fourth, benefits and taxes had no substantial impact on unemployment during this period. This is in line with Giesecke (2008) who examines the period 1996/97-2001/02 and concludes that his results "are not suggestive of policy changes having exerted a large influence on either GDP or consumption growth" [p. 36]. Nevertheless, we find that the abolition of the Accord contributed to the fall in the unemployment rate (its abolition in 1995 led to a 2.3 pp reduction).

Note that the Accord's objective was to put in a brake to the large average real wage increases of the mid 1970s, which were seen as responsible for the rising unemployment rates of the following several years. However, Gregory (2000) argues that, although average real wages did not increase during the Accord period, the resulting labour shift affected mainly women (since employment growth was directed primarily towards part-time jobs and jobs traditionally held by women). In particular, "The jobs did not reduce the unemployment rate but added to the participation rate of women" [p. 123]. Therefore, our finding (namely, that the absence of the incomes policy led to a fall in unemployment) is in line with Gregory (2000) under the provision that the labour force curve (mainly on the women's side) shifted inwards by more than the labour demand curve did.

Furthermore, the 1990s was also a period of fiscal consolidation (Figure 2e). According to Song and Freebairn (2006) this consolidation had an overall positive effect on the Australian economy, mainly because it allowed the fall in interest rates. According to our simulation findings, the reduction in government expenditures led to an unemployment increase of 2.1 pp (Figure 4d). This was the direct effect of the cutbacks in public spending since 1993, which may have also had compensating macroeconomic effects through lower interest rates or via other indirect routes (in the form of changes in the various exogenous variables of the model).

Finally, as in the 1973-1983 period, the contribution of financial wealth to the unemployment trajectory is negligible.

\section{Conclusions}

In this paper we examined the evolution of Australian unemployment using the CRT methodology. The CRT differs from mainstream approaches in two key aspects. First, rather than estimating single-equation reduced-form unemployment models (such as Nickell, 1997, or Blanchard and Wolfers, 2000), it analyses multi-equation labour market models featuring dynamics and spillovers. Second, in contrast to the NAIRU multi-equation models, the CRT does not impose a-priori restrictions so that growing variables cannot affect the time path of the unemployment rate. We showed that the interplay between lagged adjustment processes 
and growing variables generates frictional growth, which implies that actual unemployment does not gravitate towards its natural rate in the long run. In other words, the phenomenon of frictional growth challenges the pivotal role of the NRU in assessing the performance of labour markets.

Our empirical model took into account different sources of labour market dynamics (due to adjustments in employment, wage setting and labour participation), and considered the influence of growing variables (such as capital stock, capital deepening, and working-age population) on labour market decisions. The presence of growing variables in the set of driving forces of unemployment also questions the conventional story that shocks, institutions, and their interactions are solely responsible for the ups and downs of the unemployment rate. We checked the statistical and economic "health" of our labour market model in a variety of ways: the goodness of fit, standard diagnostic tests, the consistency of our ARDL cointegrating vectors with the those obtained by the Johansen technique, and the plausibility of the univariate representation of unemployment.

We then evaluated how each of the exogenous variables in our labour market system contributed to (i) the rise in unemployment over the 1973-1983 period, and (ii) the prolonged unemployment decline during the 1993-2006 years. Our results for the 1970s and early 1980s reaffirm the widely accepted story that shocks to interest rates and commodity prices (e.g. oil price and terms of trade), together with institutions (in the form of taxes and benefits) were responsible for the rise in unemployment. In addition, capital accumulation and government expenditures played a significant role in the second half of the 1970s. The latter in the form of a Keynesian reaction to the crisis from the short-lived labour party government.

For the 1990s and early 2000s we depict a completely different story, one that contradicts conventional wisdom. While capital accumulation was the main driving force of the unemployment rate, institutions, oil price and interest rate shocks played no role in the unemployment decline. The external factors were also crucial, but with counterbalancing effects between the boom in the terms of trade and the recent sharp decrease in net foreign demand.

Overall, our findings indicate that the performance of the labour market has become less dependent on the institutional setting, whilst capital accumulation together with the Australian position in the international markets have become more influential. Hence, confining the framework of labour market analysis to trendless variables, wage rigidities and a parcel of temporary shocks can only provide a partial view of the unemployment problem and offer questionable policy advice.

\section{References}

[1] Agnese, P. and Sala, H. (2009): "The fading 1990s in Japan: driving forces behind the unemployment upsurge", International Review of Economics and Finance, forthcoming (doi: 10.1016/j.iref.2008.09.005). 
[2] Arestis, P., Baddeley, M. and Sawyer, M. (2007): "The relationship between capital stock, unemployment and wages in nine EMU countries", Bulletin of Economic Research, vol. 59 (2), pp. 125-148.

[3] Australian Treasury (2006): "2005-06 in review: high terms-of-trade, low unemployment", Economic Roundup, Spring, pp. 131-146, The Treasury - Australian Government.

[4] Ball, L. and Mankiw, N.G. (2002): "The NAIRU in theory and practice", Journal of Economic Perspectives, vol. 16 (4), pp. 115-136.

[5] Bande, R. and Karanassou, M. (2009): "Labour market flexibility and regional unemployment rate dynamics: Spain 1980-1995", Papers in Regional Science, forthcoming (doi:10.1111/j.1435-5957.2008.00165.x).

[6] Banks, R. (2001): "The role of ICT in Australia's economic performance", Presentation to the Communications Research Forum, Rydges Lakeside, Canberra, 26 September 2001.

[7] Bean, C.R., Layard, R. and Nickell, S.J. (1986): "The rise in unemployment: a multi-country study", Economica, vol. 53, pp. 1-22.

[8] Blanchard, O. and Wolfers, J. (2000): "The role of shocks and institutions in the rise of European unemployment: the aggregate evidence", The Economic Journal, vol. 110, pp. C1-C33.

[9] Crosby, M. and Olekalns. N. (1998): "Inflation, unemployment and the NAIRU in Australia", The Australian Economic Review, vol. 31 (2), pp. 117-129.

[10] Debelle, G. and Vickery, J. (1998): "Is the Phillips curve a curve? Some evidence and implications for Australia", The Economic Record, vol. 74 (227), pp. 204-214.

[11] Dixon, R., Freebairn, J. and Lim, G.C. (2005): "An employment equation for Australia", The Economic Record, vol. 81 (254), pp. 204-214.

[12] Dowrick, S. and Wells, G.M. (2004): "Modelling aggregate demand for labour: a critique of Lewis and MacDonald", The Economic Record, vol. 80 (251), pp. 436-440.

[13] Giesecke, J. (2008): "The effects of recent structural, policy and external shocks to the Australian economy, 1996/97-2001/02", Australian Economic Papers, vol. 47 (1), pp. 15-37.

[14] Gregory, R.G. (2000): "The impact of labour-market and economic reforms in the UK, New Zealand, Australia and the US", in S. Bell (ed.) The Unemployment Crisis in Australia, pp. 104-24, Cambridge University Press, Melbourne.

[15] Groenewold, N. (2003): "Long-run shifts of the Beveridge curve and the frictional unemployment rate in Australia", Australian Journal of Labour Economics, vol. 6, pp. 65-82.

[16] Groenewold, N. and Hagger, A.J. (1998): "The natural unemployment rate in Australia since the seventies", The Economic Record, vol. 74 (224), pp. 24-35.

[17] Groenewold, N. and Hagger, A.J. (1999): "A 'Lilien' natural rate series for Australia: a reply", The Economic Record, vol. 75 (229), pp. 173-176.

[18] Groenewold, N. and Hagger, A.J. (2000): "The natural rate of unemployment in Australia: estimates from a structural VAR", Australian Economic Papers, vol. 39 (2), pp. 121-137.

[19] Gruen, D., Pagan, A., and Thompson, C. (1999): "The Phillips Curve in Australia", Journal of Monetary Economics, vol. 44, pp. 235-58.

[20] Gruen, D. (2006): "A tale of two terms-of-trade booms", Address to the Australian Industry Group's Economy Forum, 1 March 2006, Melbourne. 
[21] Hagger, A.J. and Groenewold, N. (2003): "Time to Ditch the Natural Rate?", The Economic Record, vol. 79 (246), pp. 324-335.

[22] Heaton, C. and Oslington, P. (2002): "The contribution of structural shocks to Australian unemployment", The Economic Record, vol. 78 (243), pp. 433-442.

[23] Henry, S.G.B., Karanassou, M. and Snower, D.J. (2000): "Adjustment dynamics and the Natural Rate", Oxford Economic Papers, vol. 52, pp. 178-203.

[24] McDonald, J. (1999): "A most unnatural unemployment rate for Australia", The Economic Record, vol. 75 (229), 167-70

[25] McDonald, I.M. (2008): "Full employment: is there a good reason to be falling short?", The Australian Economic Review, vol. 41 (3), pp. 283-285.

[26] Madden, G. and Savage, S.J. (1998): "Sources of Australian labour productivity change 19501994", The Economic Record, vol. 74 (227), pp. 362-372.

[27] Kapadia, S. (2005): "The capital stock and equilibrium unemployment: a new theoretical perspective", Discussion Paper Series 181, Department of Economics, University of Oxford.

[28] Karanassou, M., and Sala, H. (2008): "Productivity Growth and the Phillips Curve: A Reassessment of the US Experience", School of Economics Discussion Paper, 2008/06, UNSW Australian School of Business, UNSW, Sydney.

[29] Karanassou, M., and Sala, H. (2009): "The rise and fall of Spanish unemployment: a Chain Reaction Theory perspective", forthcoming in Arestis, P. and Sawyer, M. (eds.), International Papers in Political Economy, Palgrave Macmillan, New York.

[30] Karanassou, M., Sala, H., and P. F. Salvador (2008): "Capital Accumulation and Unemployment: New Insights on the Nordic Experience", Cambridge Journal of Economics, vol. 32 (6), pp. 977-1001.

[31] Karanassou, M., Sala, H. and Snower, D.J. (2003): "Unemployment in the European Union: a dynamic reappraisal", Economic Modelling, vol. 20 (2), pp. 237-273.

[32] Karanassou, M., Sala, H. and Snower, D.J. (2008): "The evolution of inflation and unemployment: explaining the roaring nineties", Australian Economic Papers, vol. 47 (4), pp. 334-354.

[33] Karanassou, M., Sala, H. and Snower, D.J. (2009): "Phillips curves and unemployment dynamics: A critique and a holistic perspective", Journal of Economic Surveys, forthcoming.

[34] Karanassou, M. and D.J. Snower (2004): "Unemployment invariance", The German Economic Review, vol. 5 (3), pp. 297-317.

[35] Kennedy, S., Luu, N., and Goldbloom, A. (2008): "Examining full employment in Australia using the Phillips and Beveridge curves", The Australian Economic Review, vol. 41 (3), pp. $286-297$.

[36] Layard, R., Nickell, S.J. and Jackman, R. (1991): Unemployment: Macroeconomic Performance and the Labour Market, Oxford: Oxford University Press.

[37] Lewis, P.E.T. and Kirby, M.G. (1988): "A new approach to modelling the effects of incomes policies", Economics Letters, vol. 28, pp. 81-85.

[38] Lewis, P.E.T. and MacDonald, G. (2002): "The elasticity of demand for labour in Australia", The Economic Record, 78, pp. 18-30. 
[39] Lewis, P.E.T. and MacDonald, G. (2004): "Modelling aggregate demand for labour: a reply to Dowrick and Wells", The Economic Record, 80 (251), pp. 441-444.

[40] Lilien, D.M. (1982): "Sectoral shifts and cyclical unemployment", The Journal of Political Economy, vol. 90 (4), pp. 777-793

[41] Lindbeck, A. and Snower, D.J. (1994): "How are product demand changes transmitted to the labour market?", The Economic Journal, 104, pp. 386-398.

[42] Lye, J.N. and McDonald, I.M. (2006): "John Maynard Keynes meets Milton Friedman and Edmond Phelps: The range versus the natural rate in Australia, 1965:4 to 2003:3", Australian Economic Papers, vol. 45 (3), pp. 227-240.

[43] Lye, J.N., McDonald, I.M., and Sibly, H. (2001): "An estimate of the range of equilibrium rates of unemployment for Australia", The Economic Record, vol. 77 (236), pp. 35-50.

[44] Malley, J. and Moutos, T. (2001): "Capital accumulation and unemployment: a tale of two continents", The Scandinavian Journal of Economics, vol. 103 (1), pp. 79-99.

[45] Newell, A. and Simons, J.S.V. (1985): "Wages and unemployment in OECD countries", Centre for Labour Economics Discussion Paper 219, London School of Economics, London.

[46] Nickell, S.J. (1997): "Unemployment and labour market rigidities: Europe versus North America", Journal of Economic Perspectives, 11 (3), pp. 55-74.

[47] Nickell, S.J., Nunziata, L. and Ochel, W. (2005): "Unemployment in the OECD since the 1960s. What do we know?", The Economic Journal, 115, pp. 1-27.

[48] OECD: OECD Economic Surveys: Australia, years 1998, 1999, 2000, 2001, 2003, 2004, 2006.

[49] O’Neill, P. and B. Fagan (2006): "Geographical Takes on Three Decades of Economic Reform in Australia", Geographical Research, vol. 44 (2), pp. 204-219.

[50] Parham, D. (2004): "Sources of Australia's productivity revival", The Economic Record, vol. 80 (249), pp. 239-257.

[51] Pesaran, M.H. (1997): "The role of economic theory in modelling the long run", The Economic Journal, vol. 107, pp. 178-191.

[52] Pesaran, M.H. and Y. Shin (1999): "An Autoregressive Distributed-Lag Modelling Approach to Cointegration Analysis" in Strom, S. (ed.), Econometrics and Economic Theory in the Twentieth Century: The Ragnar Frisch Centennial Symposium, Cambridge University Press, pp. 371-413.

[53] Pesaran, M.H., Shin, Y. and Smith, R.J. (2001): "Bounds testing approaches to the analysis of level relationships", Journal of Applied Econometrics, 16, pp. 289-326.

[54] Pissarides, C.A. (1991): "Real wages and unemployment in Australia", Economica, 58, pp. $35-55$.

[55] Rowthorn, R. (1999): "Unemployment, wage bargaining and capital-labour substitution", Cambridge Journal of Economics, vol. 23, pp. 413-425.

[56] Song, L.L. and Freebairn, J. (2005): "Policies to reduce unemployment: simulations with Treasury macroeconomic model", The Economic Record, vol. 81 (255), pp. 351-366.

[57] Song, L.L. and Freebairn, J. (2006): "How big was the effect of budget consolidation on the Australian economy in the 1990s?", The Australian Economic Review, vol. 39 (1), pp. 35-46.

[58] Webster, E. (2003): "The effects of wages on aggregate employment: a brief summary of empirical studies", The Australian Economic Review, vol. 36 (1), pp. 134-142. 